\title{
HOARDING OF INTERNATIONAL RESERVES: MRS MACHLUP'S WARDROBE AND THE JONESES
}

\author{
YIN-WONG CHEUNG \\ XING WANG QIAN
}

\author{
CESIFO WORKING PAPER NO. 2065 \\ CATEGORY 6: MONETARY POLICY AND INTERnAtional FinANCE \\ JULY 2007 \\ Presented AT CESifo AREA CONFERENCE ON \\ MaCro, Money \& InTERnAtional FinANCE, FEBrUARY 2007
}
An electronic version of the paper may be downloaded
- from the SSRN website:
- from the RePEc website:
http://www.SSRN.com/abstract $=1002884$
www.RePEc.org
- from the CESifo website:
www.CESifo-group.de




\title{
HOARDING OF INTERNATIONAL RESERVES: MRS MACHLUP’S WARDROBE AND THE JONESES
}

\begin{abstract}
Motivated by the observed international reserve hoarding behavior in the post-1997 crisis period, we explore the Mrs Machlup's wardrobe hypothesis and the related keeping up with the Joneses argument. It is conceived that, in addition to psychological reasons, holding a relatively high level of international reserves reduces the vulnerability to speculative attacks and promotes growth. A stylized model is constructed to illustrate this type of hoarding behavior. The relevance of the keeping up with the Joneses effect is examined using a few plausible empirical specifications and data from 10 East Asian economies. Panel-based regression results are suggestive of the presence of the Joneses effect; especially in the post1997 crisis period. Individual economy estimation results, however, show that the Joneses effect varies across economies.
\end{abstract}

JEL Code: F3, F4.

Keywords: demand for international reserves, excessive international reserve accumulation, speculative attack, keeping up with the Joneses.

\author{
Yin-Wong Cheung \\ Department of Economics, E2 \\ University of California \\ Santa Cruz, CA 95064 \\ USA \\ cheung@ucsc.edu
}

\author{
Xing Wang Qian \\ Department of Economics, E2 \\ University of California \\ Santa Cruz, CA 95064 \\ USA \\ xqian@ucsc.edu
}

First Version: January 2006

This Version: July 2007

We thank Joshua Aizenman, Michel Beine, Ken Chan, Charles Engel, Jakob de Haan, Mathias Hoffmann, Paul de Grauwe, Fred Kwan, Guy Meredith, Marc-Andreas Muendler, Assaf Razin, Eli Remolona, Gunther Schnabl, Pierre Siklos, Yong Wang, Frank Westermann and participants of the 2006 Fourth HKIMR Summer Workshop, the Hong Kong City University seminar, and 2007 CESifo Area Conference on Macro, Money and International Finance for their helpful comments and suggestions. Cheung acknowledges the financial support of faculty research funds of the University of California, Santa Cruz. 


\section{Introduction}

The 1997 financial crisis in East Asia underscores the importance of capital account variability and the role of flow reversal on triggering off a crisis. Economies in the crisisinflicted region appear to have adjusted their policy behavior and have sharply boosted their international reserves in the aftermath of the crisis. For instance, China, Japan, Korea, Malaysia and Taiwan; the economies that are commonly mentioned in the recent discussion/debate of the extraordinary and puzzling accumulation of international reserves in the new millennium, see their international reserves increased by, respectively, 388\%, 135\%, 119\%, 138\% and 137\% between 2000 and 2005. ${ }^{1}$

The steep increase in international reserves definitely helps these economies to deter speculative attacks. Nonetheless, the dramatic jumps in international reserve holdings raise concerns in both policy and academic circles. In general, it is perceived that some of these economies are holding international reserves at a level that is difficult to be rationalized by conventional factors. For instance, one traditional indicator of international reserve adequacy is the reserves-to-imports ratio and the rule of thumb is to maintain international reserves worth, say, three months of imports.

Again, consider China, Japan, Korea, Malaysia and Taiwan - their holdings of international reserves are much higher than the three-month benchmark. Specifically, at the end of 2005, the international reserves held by these economies cover, respectively, 14.93, 19.33, 9.66, 7.36, and 16.65 months of imports. While excessive international reserves offer some benefits, they carry substantial negative implications for both domestic economies and global imbalances, and thus, can be a serious threat to the stability of the world economy.

Existing theories offer a few reasons for holding international reserves. One common explanation is the precautionary demand motivated by trade financing considerations. ${ }^{2}$ The recent literature has extended the precautionary motive and considers accumulation of international reserves a policy to avoid crisis-induced output losses and investment contractions. ${ }^{3}$

$1 \quad$ Based on data from the April 2006 IFS data CD.

2 See, for example, Grubel (1971) for a survey of the pre-1970 studies. Flood and Marion (2002) review the theory and provide some recent empirical evidence. Genberg et al. (2005) discuss some specifics related to Asia.

3 See, for example, Aizenman et al. (forthcoming), Jeanne and Rancière (2006), and Lee (2004). 
Conditions in the financial market are also deemed important determinants of the holding of international reserves. For instance, the popular Greenspan-Guidotti rule recommends that developing economies should hold international reserves to cover short-term external debts. In general, it is advisable to cover the one year amortized value of various types of liabilities over a wide range of possible outcome. ${ }^{4}$ Apparently, these factors do not fully explain the surge in international reserves witnessed in the new millennium.

In a series of articles Dooley, Folkerts-Landau and Garber (2005) argue that the large hoarding of international reserves by East Asian economies is a natural consequence of the presence of a revived Bretton Woods system in the region. In essence, these economies adopt the mercantilist approach, pursue the export-led growth strategy followed by the post-war Europe and Japan, and, hence, accumulate international reserves. According to their view, international reserve accumulation is a by-product of the development strategy that promotes exports with an undervalued currency. Aizenman and Lee (2005), however, find that even though the mercantilist motive is confirmed by the data, it has little economic significance in explaining the buildup of international reserves in the post-crisis era.

In the current study, we explore an idea advanced by Machlup (1966) and assess the extent to which his idea is relevant for explaining the international reserve accumulation behavior of some East Asian economies. Fritz Machlup, after examining some measures of international reserves, argued that the observed holding patterns could not be explained by reasons offered "by either theorists or practitioners.” Instead, he suggested monetary authorities' hoarding of international reserves can be driven by non-fundamental factors. Specifically, he used his wife's need for dresses as a metaphor to exemplify the monetary authorities' desire for more and more international reserves.

Apparently, the recent ascent in the holding of international reserves and some related official remarks lend credibility to the Mrs Machlup’s Wardrobe analogy. For instance, an official in the Korea's central bank said “(T)here is no such thing as too much foreign international reserves.” On China’s international reserve holding, a Chinese official argued that

$4 \quad$ The rule follows from the former Federal Reserve Chairman Alan Greenspan's comments on Pablo Guidotti's insight on the role of external debts in 1999. See Greenspan (1999). Guidotti is a former Deputy Minister of Finance of Argentina. de Beaufort Wijnholds and Kapteyn (2001), on the other hand, argue that the domestic liability represented by money supply should also be considered. 
there is "no unified benchmark on the appropriate amount of forex international reserve a country should hold in both theory and practice" and "it could not be said to be "excessive" or "deficient." The official statements usually point to the need of building up international reserves to fend off external shocks and speculative attacks but do not offer a target level based on fundamental considerations. Even with the anecdotal evidence, is it reasonable to assert that the insatiable appetite of central banks for international reserves is the sole reason for the recent buildup of international reserves?

We postulate that the international reserve accumulation process pertaining to the Mrs Machlup's Wardrobe metaphor may serve some relevant economic purposes. It is quite noncontroversial to state that, on the other things being equal basis, international reserves help absorb unexpected (external) shocks and smooth current and capital account imbalances. The crisis experience and the development after the crisis appear to be consistent with the notion of accumulating international reserves to forestall future speculative attacks. The question, of course, is how high the level of international reserves an economy has to hold?

On his wife’s dress need, Machlup (1966, p. 26) suggests that it depends “on the Joneses with whom she wishes to keep up.” That is, besides some fundamental considerations, the buildup of international reserves depends on the behavior of neighboring economies. Ignoring the question of why Mrs Machlup has to keep up with the Joneses for a moment, the (implicit) rivalry among economies may give raise to competitive hoarding mechanism that pushes the holding of international reserves to a level that is difficult to be explained by only traditional considerations.

Besides the pure psychological desire to feel good and not to be perceived as inferior, there are a few reasons why economies would like to keep up with their peers. Remarks by Feldstein (1999) and Fischer (1999), for example, offer some insight on the keeping up with the Joneses motivation. After the crisis, these two noted economists observed that economies with a higher level of international reserves survived the East Asian financial crisis better than those with a lower level. Thus, a level of international reserves that is relatively higher than your neighbors may diffuse the speculative pressure on your own economy and divert it to the neighboring economies and, hence, reduce the chance of bearing the full cost of an attack. In other words, when a financial crisis is brewing in the region, if two economies have similar

$5 \quad$ Day and Choi (2004) and Xinhua News Agency (2004). 
economic fundamentals, the one with a higher level of international reserves is less likely to be attacked and more likely to survive the crisis.

Another reason for keeping up with the Joneses is that international reserves can have a positive impact on an economy's output prospects. If the level of international reserves is a barometer of financial heath, an economy has an additional incentive to keeping up with the Joneses to position itself to compete for international capital and foreign direct investment, which tend to have a level of productivity proficiency higher than the domestic capital. For developing economies, the output effect of international reserves also arises from their ability to reduce costs of borrowing in the international capital market and provide needed liquidity when there is a reversal of capital flows. A relatively high level of international reserves will, thus, provide a catalyst for economic growth and enhance output prospects, which in turn will improve the market sentiment and, hence, reduce an economy's vulnerability to attack.

In the remaining part of the paper, we use a stylized model to illustrate the demand for international reserves when Mrs Machlup takes the Joneses into consideration. Specifically, we assume that an economy's vulnerability to speculative attacks depends on, among other things, international reserves held by other economies. The exercise also underscores the international reserve's feedback on output potential and the related Joneses effect. Further, we take the idea to the data from a group of East Asian economies and investigate whether these economies display the keeping up with the Joneses behavior.

\section{International Reserve Hoarding and Keeping up with the Joneses}

In this section, we present a sequence of models to illustrate the demand for international reserves in the presence of keeping up with the Joneses due to a) the consideration of speculative attack, and b) the feedback effect of international reserves on output. The first model serves as a benchmark, the second one modifies the speculative attack probability to accommodate the notion of keeping up with the Joneses, and the third one introduces a positive output effect of international reserves.

A caveat is in order. The following discussion highlights two possible situations that lead to the keeping up with the Joneses effect. Similar to the implicit psychological motivation in Machlup (1966), any mechanisms that give rise to competitive hoarding behavior will generate the keeping up with the Joneses effect described in this and the next section. 


\subsection{The Benchmark Model}

In this subsection, we derive the baseline demand for international reserves. The basic structure is essentially the model used by Aizenman et al. (forthcoming). A few simplifications were implemented to reduce the complexity of the model and highlight the issue we would like to analyze. For this reason, we refer interested readers to Aizenman et al. (forthcoming) for a more detailed description.

We consider a two-period model. In period one the economy has an output endowment $Y_{l}$. Without loss of generality, the initial endowment is normalized to 1 ; that is $Y_{1}=1$. The output in the second period $Y_{2}$ is a random variable given by

$$
Y_{2}=\left\{\begin{array}{ccc}
1+\delta & \text { with probability } & 1-p \\
1-\varepsilon & \text { with probability } & p
\end{array} ; \delta, \varepsilon>0 \text { and } 0<p<1 .\right.
$$

The random output shocks $\delta$ and $\varepsilon$ are not necessarily the same. The probability that the economy suffers from output losses due to a speculative attack is $p$. For simplicity, we ignore attacks that do not have any output implications. ${ }^{6}$ For the benchmark model, we assume $p$ is given by

$$
p=\phi+\alpha \frac{B}{R}, \quad \alpha>0,
$$

where $R$ and $B$ are, respectively, the level of international reserve holding and the amount of foreign borrowing in period 1. In essence, (2) assumes the probability of suffering an attack that leads to an output loss is inversely related to the level of international reserves and directly proportional to the level of indebtedness. $\alpha$ is a scale parameter to ensure that the output loss probability $p$ stays within the legitimate region. $\phi$ is a catch-all parameter representing other factors that affect the attack probability. We label the occurrence of $1+\delta$ a good state and that of $1-\varepsilon$ a bad state.

During the first period, given the output $Y_{l}$, the economy makes decisions regarding consumption $\left(C_{1}\right)$, international reserve accumulation $(R)$ and borrowing in the international capital market $(B)$, and is subject to the budget constraint

$6 \quad$ It means the probability $(1-p)$ includes these events: 1$)$ no speculative attack; 2$)$ a speculative attack has been neutralized or defended without output loss; 3) any other speculative attacks that do not induce an output drop. Also, we ignore output losses due to factors other than speculative attacks. 


$$
C_{1}=1+B-R \text {. }
$$

The international borrowing carries a contractual interest rate $r$ and, thus, the required repayment in period 2 is $(1+r) B$.

Because of a possible default in the second period, the economy faces a credit ceiling that limits the amount it can borrow internationally. The credit ceiling can be determined as follows. In the case of default, we assume the international lender can confiscate a share of $Y_{2}$, denoted by $\theta Y_{2} ; 0<\theta<1$, from the economy. However, the international lender does not have access to the economy's international reserves. If the repayment $(1+r) B$ is larger than the penalty $\theta Y_{2}$, then the economy has an incentive to default. Thus, the international lender would determine the lending amount knowing that the repayment he is going to receive in period 2 is

$$
S=M I N\left[(1+r) B ; \theta Y_{2}\right],
$$

where $M I N[.,$.$] is the minimum operator. Let the (international) risk-free interest rate be r *$. It is assumed that $r>r *{ }^{7}$ Under risk neutrality, the expected repayment is given by

$$
E[S]=\left(1+r^{*}\right) B \text {. }
$$

The credit ceiling, $\bar{B}$, faced by the economy is the level of debt that will lead to a default in both good and bad states. Thus, it is given by

$$
\bar{B}=\frac{(1-p) \theta(1+\delta)+p \cdot \theta(1-\varepsilon)}{1+r^{*}}=\frac{\theta(1+\delta)-p \theta(\delta+\varepsilon)}{1+r^{*}} .
$$

The credit ceiling is increasing with the positive production shock $\delta$ and the ability to confiscate $\theta$, and is decreasing with the adverse production shock $\varepsilon$, the probability of an attack that leads to output losses $p$, and the risk free rate $r^{*}$.

Assuming a) $(1+r) B \leq \theta(1+\delta)$, b) $(1+r) B>\theta(1-\varepsilon)$ with the probability $q$, and c) the international reserves earn an interest rate of $r^{*}$, the budget constraint for the second period is given by $^{8}$

$7 \quad$ The Appendix shows that the economy has to pay a premium in the international capital market; that is $r>r^{*}$

8 The economy defaults in the bad state if $1-\varepsilon-(1+r) B<(1-\theta)(1-\varepsilon)$, which can be simplified to the condition $(1+r) B>\theta(1-\varepsilon)$. Thus, $q$ is the default probability under the bad state and depends on the adverse output shock $\varepsilon$. 


$$
C_{2}=\left\{\begin{array}{llc}
C_{2, g}=1+\delta-(1+r) B+\left(1+r^{*}\right) R & \text { with probability } & 1-p \\
C_{2, b}=1-\varepsilon-(1+r) B+\left(1+r^{*}\right) R & \text { with probability } & p \cdot(1-q), \\
C_{2, b, d}=(1-\theta)(1-\varepsilon)+\left(1+r^{*}\right) R & \text { with probability } & p \cdot q
\end{array}\right.
$$

where $C_{2, g}, C_{2, b}, C_{2, b, d}$ are, respectively, the levels of consumption in period 2 when the economy is in the good state, in the bad state with no default, and in the bad state and defaulted.

The economy has to choose the levels of consumption $C_{1}$ and $C_{2}$ to maximize its representative consumer's expected utility, which is given by

$$
U(.)=C_{1}+\frac{1}{1+\rho}\left[(1-p) C_{2, g}+p\left[(1-q) C_{2, b}+q C_{2, b, d}\right]\right],
$$

where $\rho$ is the discount rate and is assumed to be larger than the risk-free interest rate $r *$. Taking the output loss probability (2) and the budget constraints (3) and (7) into consideration, the task is to maximize the expected utility $U($.) subject to the conditions (2), (3), and (7). In solving the utility maximization problem, we should obtain the optimal levels of borrowing and international reserves along with the optimal consumption path.

To simplify the presentation, we follow Aizenman et al. (forthcoming) and assume that the economy has a discount rate high enough to set the borrowing at the ceiling level $\bar{B}$. When $B$ $=\bar{B}$, the contractual (not the expected) repayment is

$$
\left.B(1+r)\right|_{B=\bar{B}}=\theta(1+\delta),
$$

and the expected utility $U($.$) can be written as$

$$
\left.U(.)\right|_{B=\bar{B}}=(1+\bar{B}-R)+\frac{1}{1+\rho}\left\{(1-\theta)(1+\delta)+\left(1+r^{*}\right) R-p(1-\theta)(\delta+\varepsilon)\right\} .
$$

Thus, the first order condition with respect to $R$ is

$$
1-\left.\frac{d B}{d R}\right|_{B=\bar{B}}=\frac{1}{1+\rho}\left[\left(1+r^{*}\right)-\left.(1-\theta)(\delta+\varepsilon) \frac{d p}{d R}\right|_{B=\bar{B}}\right],
$$

which equates the marginal cost of increasing one unit of $R$ in period one to the resulting (discounted) benefit obtained in period two.

Next, we derive $\left.\frac{d B}{d R}\right|_{B=\bar{B}}$ and $\left.\frac{d p}{d R}\right|_{B=\bar{B}}$ from (2) and (6) and substitute the results in (10) to obtain

$$
\left[\left(1+r^{*}\right) R+\alpha \theta(\delta+\varepsilon)\right]^{2}
$$




$$
=\frac{(\delta+\varepsilon)\left[\left(1+r^{*}\right)+\theta\left(\rho-r^{*}\right)\right][\alpha \theta(1+\delta)-\alpha \theta \phi(\delta+\varepsilon)]}{\left(\rho-r^{*}\right)} .
$$

Thus, the optimal level of international reserves is

$$
R_{b}=\left\{\frac{(\delta+\varepsilon)\left[\left(1+r^{*}\right)+\theta\left(\rho-r^{*}\right)\right][\alpha \theta(1+\delta)-\alpha \theta \phi(\delta+\varepsilon)]}{\left(1+r^{*}\right)^{2}\left(\rho-r^{*}\right)}\right\}^{1 / 2}-\frac{\alpha \theta(\delta+\varepsilon)}{1+r^{*}} .
$$

The subscript "b" indicates that the expression is going to be used as a benchmark for comparison. From (12), it can be verified that the hoarding of international reserves is a) positively related to $(\delta+\varepsilon)$, the benefit of not being attacked and $\theta$, the share of output being confiscated when it defaults, and b) negatively related to $\left(\rho-r^{*}\right)$, the opportunity cost and $\phi$, the catch-all parameter that determines the economy's vulnerability. It is also noted that $\bar{B}$ is positively related to $R_{b}$ since $\bar{B}$ is negatively related to $p$ (equation (6)) and $p$ is negatively related to $R$ (equation (2)).

\subsection{The Joneses}

To capture the idea of "keeping up with the Joneses," we modify the probability that the economy suffers an output-loss-causing attack to

$$
p_{J}=\phi+\alpha \frac{B_{J}}{R_{J}}+\beta \frac{\tilde{R}_{0}}{R_{J}}, \quad \alpha, \beta>0,
$$

where the subscript "J" indicates the presence of the Joneses effect. $\tilde{R}_{0}$ is the average of international reserves held by its peer group (the Joneses) at period $0 .^{9}$

Equation (13) incorporates the effect of international reserves held by other economies. It captures the notion that, ceteris paribus, speculators tend to attack an economy with a relatively low level of international reserves, which are powerful ammunition against speculative attacks. In additional to its own level of international reserves, an economy has to be aware of its relative position among its peer group. Attacks can be triggered by self-fulfilling expectations that are not related to fundamentals and speculators will look for a victim that has a relatively (rather than an absolutely) high level of vulnerability. Lagged rather than current international reserves in other economies are considered because current information about other

$9 \quad$ Strictly speaking, the model is extended to a three-period model. However, the period 0 is added to accommodate $\tilde{R}_{0}$ and it has no implications for other aspects of the model. 
economies' international reserves is typically hard to obtain. ${ }^{10}$ Indeed, Mrs Machlup’s desire for dresses is likely to be instigated by seeing her contemporaries’ collection.

With the output loss probability specified by (13) rather than (2), the demand for international reserves in the presence of the Joneses effect can be derived by maximizing the expected utility $U($.$) in (8) subject to the conditions (13), (3), and (7). We follow a similar$ strategy and consider borrowing at the ceiling. In this case, the credit ceiling is given by

$$
\bar{B}_{J}=\frac{\theta(1+\delta)-p_{J} \theta(\delta+\varepsilon)}{1+r^{*}},
$$

and the corresponding first order condition is given by

$$
1-\left.\frac{d B}{d R}\right|_{B=\bar{B}_{J}}=\frac{1}{1+\rho}\left[\left(1+r^{*}\right)-\left.(1-\theta)(\delta+\varepsilon) \frac{d p}{d R}\right|_{B=\bar{B}_{J}}\right],
$$

where the subscript " $\mathrm{J}$ " is used to indicate the presence of the Joneses effect. Thus, it can be shown that

$$
\begin{aligned}
& {\left[\left(1+r^{*}\right) R_{J}+\alpha \theta(\delta+\varepsilon)\right]^{2}} \\
& =\frac{(\delta+\varepsilon)\left[\left(1+r^{*}\right)+\theta\left(\rho-r^{*}\right)\right]\left[\alpha \theta(1+\delta)-\alpha \theta \phi(\delta+\varepsilon)+\left(1+r^{*}\right) \beta \tilde{R}_{0}\right]}{\left(\rho-r^{*}\right)},
\end{aligned}
$$

and the optimal level of international reserves is

$$
\begin{aligned}
R_{J}= & \left\{\frac{(\delta+\varepsilon)\left[\left(1+r^{*}\right)+\theta\left(\rho-r^{*}\right)\right]\left[\alpha \theta(1+\delta)-\alpha \theta \phi(\delta+\varepsilon)+\left(1+r^{*}\right) \beta \tilde{R}_{0}\right]}{\left(1+r^{*}\right)^{2}\left(\rho-r^{*}\right)}\right\}^{1 / 2} \\
& -\frac{\alpha \theta(\delta+\varepsilon)}{1+r^{*}} .
\end{aligned}
$$

Similar to $R_{b}$ in (12), the demand for international reserves in the presence of the Joneses increases with $(\delta+\varepsilon)$ and $\theta$, and decreases with $\left(\rho-r^{*}\right)$ and $\phi$. Through their impact on the attack probability, the international reserves held by others have a positive implication for an economy's own hoarding of international reserves. Further, an economy's level of international reserves is positively related to its sensitivity to the Joneses effect as measured by $\beta$.

10 Abel (1990) studies a model in which an individual's current consumption depends on the lagged aggregated consumption. He suggested the use of the phrase "catching up with the Joneses" instead of "keeping up with the Joneses" to reflect the dependence on lagged consumption. Nonetheless, we stay with Machlup’s original wording for consistence. 
Comparing (12) and (16), it can be seen that the positive term $\left(1+r^{*}\right) \beta \widetilde{R}_{0}$ is the only difference between $R_{b}$ and $R_{J}$. Thus, $R_{J}$ is larger than $R_{b}$ - the demand for international reserves is higher in the presence of the Joneses effect, ceteris paribus. An economy's optimal level of international reserves is higher than the one justified by fundamentals alone when its probability of being attacked is adversely affected by international reserves held by other economies. Given the possibility of being victimized and suffering output losses from speculative attacks with a relatively low level of international reserves, an economy's rational response is to incorporate others' behavior into its own decision making process.

\section{$2.3 \quad$ Feedback on Output Outlook}

In this subsection, we modify the model in subsection 2.2 and incorporate the output effect of international reserves. It is shown that economies will be encouraged to accumulate international reserves if the accumulation can improve their output outlook.

Recently, Aizenman and Lee (2005) adapt a model by Diamond and Dybvig (1983) to show that international reserves enhance output performance by providing the necessary liquidity to avert the damaging output effect of capital flight/sudden stop shocks.

Intuitively, holding of international reserves can affect output via a few channels. For instance, international reserves can smooth trade imbalances and, hence consumption. For most developing economies, a high level of international reserves helps reduce the premium they have to pay for borrowing in the global financial market. Both a smooth consumption stream and a low borrowing cost are good for economic growth. Further, the level of international reserves can serve as an indicator of financial health and stability of an economy. Thus, a high level of international reserves helps developing economies to attract foreign direct investment, which tends to boost domestic growth.

To illustrate the implication for international reserve demand in the current framework, we refine our specification of output shocks in the second period (equation (1)) to

$$
\delta=\delta^{*}+R_{J, F} / \tilde{R}_{0},
$$

and

$$
\varepsilon=\varepsilon^{*}-R_{J, F} / \tilde{R}_{0} .
$$


To facilitate comparison, the expression $R_{J, F} / \tilde{R}_{0}$ is introduced to the output shocks to capture the output effect of international reserves. The subscript " $J, F$ " signifies both the Joneses effect and the feedback on output are under consideration. We assume the effects of international reserves on output are the same in both the good and bad states to simplify derivation. ${ }^{11}$ The presence of $\tilde{R}_{0}$ suggests the output effect depends on the relative rather than the absolute holding level of international reserves. For instance, in making a foreign direct investment decision, an entrepreneur would consider if the financial health of an economy is better than the alternatives. Thus, if the level of international reserves is an indicator, then the relative level will determine which economy will get the investment, ceteris paribus. If the positive output effect of international reserves outweighs the output loss induced by speculative attack; that is $\varepsilon^{*}<R_{J, F} / \tilde{R}_{0}$, we have the result described by Aizenman and Lee (2005).

With the modified output $Y_{2}$ given by (17), the budget constraint (7) is modified to

$$
C_{2}=\left\{\begin{array}{llc}
C_{2, g}=1+\delta-(1+r) B_{J, F}+\left(1+r^{*}\right) R_{J, F} & \text { with probability } & 1-p_{J, F} \\
C_{2, b}=1-\varepsilon-(1+r) B_{J, F}+\left(1+r^{*}\right) R_{J, F} & \text { with probability } & p_{J, F} \cdot\left(1-q_{J, F}\right) . \\
C_{2, b, d}=(1-\theta)(1-\varepsilon)+\left(1+r^{*}\right) R_{J, F} & \text { with probability } & p_{J, F} \cdot q_{J, F}
\end{array}\right.
$$

In this case, the credit ceiling $\bar{B}_{J, F}$ explicitly depends on international reserves;

$$
\bar{B}_{J, F}=\frac{\theta\left(1+\delta^{*}+R_{J, F} / \tilde{R}_{0}\right)-p_{J, F} \theta\left(\delta^{*}+\varepsilon^{*}\right)}{1+r^{*}} .
$$

We solve the utility maximization problem by maximizing $U($.$) in (8) subject to (13),$ (3), (18), and (17). That is, we incorporate the Joneses factor induced by both the speculative attack consideration and the output effect of international reserves into the utility maximization problem.

The expression of the optimal demand for international reserves, $R_{J, F}$, is given by

$$
\frac{\left(\delta^{*}+\varepsilon^{*}\right)\left[\left(1+r^{*}\right)+\theta\left(\rho-r^{*}\right)\right]\left[\alpha \theta\left(1+\delta^{*}+R_{J, F} / \tilde{R}_{0}\right)-\alpha \theta \phi\left(\delta^{*}+\varepsilon^{*}\right)+\left(1+r^{*}\right) \beta \tilde{R}_{0}\right]}{\left(\rho-r^{*}\right)\left[\left(1+r^{*}\right) R_{J, F}+\alpha \theta\left(\delta^{*}+\varepsilon^{*}\right)\right]^{2}}
$$

11 In the Appendix, we employ the Aizenman and Lee (2005) apparatus and show that output levels in both good and bad states are increasing functions of the (relative) holding of international reserves. To simplify the presentation we work with (17). 


$$
=\frac{1}{\left(1+r^{*}\right)}-\frac{\left[\left(1+r^{*}\right)+\theta\left(\rho-r^{*}\right)\right] R_{J, F}}{\left(1+r^{*}\right) R_{J, F}+\alpha \theta\left(\delta^{*}+\varepsilon^{*}\right)} .
$$

The optimal $R_{J, F}$ can be derived from (19), which is a quadratic equation in $R_{J, F}$. Instead of solving for a rather complex expression, we just note that the optimal $R_{J, F}$ is larger than the $R_{J}$ term given in (16). The result is quite intuitive. For instance, $R_{J}$ is increasing in the output shocks $\delta$ and $-\varepsilon$, which are larger than their counterparts $\delta^{*}$ and $-\varepsilon^{*} \cdot{ }^{12}$ In a word, the beneficial output effect strengthens the Joneses effect and effectuates a high level of international reserves. While most discussions focus on cushioning effects during an attack, the hoarding of international reserves can be motivated by their (indirect) contributions to economic performance during non-crisis periods. The output effect can be a significant factor for developing economies in designing their policies.

\section{Empirical Evidence}

In the previous section, we used a theoretical structure to elaborate Machlup’s (1966) contention about international reserve demand behavior. Specifically, we outlined a model to interpret the Mrs Machlup’s Wardrobe and keeping up with the Joneses argument and to illustrate the dependence of an economy's international reserve behavior on other economies' holdings of international reserves. Admittedly, the models in Section 2 are quite stylized. They are meant to demonstrate the keeping up with the Joneses effect, but not necessarily the exact relationship between international reserves held by an economy and by its neighboring economies. In the current section, we present some evidence on the relevance of the Mrs Machlup’s Wardrobe and keeping up with the Joneses argument.

Annual data from 10 Asian economies, namely China, India, Indonesia, Japan, Korea, Malaysia, Philippines, Singapore, Taiwan, and Thailand are used to assess the keeping up with the Joneses effect. These economies are located in the 1997 crisis-inflicted region. They are either adversely affected by the crisis and/or cited in the recent debate on excessive accumulation of international reserves. The sample period is from 1980 to 2004.

The demand for international reserves is investigated using the regression equations

12 The alternative representations of $R_{b}, R_{J}$, and $R_{J, F}$ given in the Appendix offer another way to compare these three variables. 


$$
\begin{aligned}
& Y_{i t}=\mathrm{c}+X_{i t}^{\prime} \alpha+\varepsilon_{i t}, \\
& Y_{i t}=\mathrm{c}+X_{i t}^{\prime} \alpha+\delta J_{i, t-1}+\varepsilon_{i t}, \text { and } \\
& Y_{i t}=\mathrm{c}+X_{i t}^{\prime} \alpha+\delta J_{i, t-1}+\psi \mathrm{I}(\mathrm{t}-1>97) * J_{i, t-1}+\varepsilon_{i t},
\end{aligned}
$$

where $i$ and $t$ are the economy and time indexes, $Y_{i t}$ is the ratio of international reserves to gross domestic product (GDP), $X_{i t}$ is the vector containing the traditional economic variables used in the literature to explain the demand for international reserves, and $J_{i, t-1}$ is the variable capturing the keeping up with the Joneses effect. Henceforth, we label $J_{i, t-1}$ "the Joneses” variable for brevity and define it later. I(.) is the indicator function. The interactive Joneses term I(t-1 > 97)* $J_{i, t-1}$ is included to investigate if there is a change in the Joneses effect in the post-1997 crisis period. The joint estimation of $\delta$ and $\psi$ helps determine if there is a change in the behavior of demand for international reserves after the 1997 East Asian financial crisis and if the Joneses effect only shows up after the crisis.

Equation (20) is a canonical specification and includes economic variables commonly considered in empirical studies of demand for international reserves. ${ }^{13}$ We normalize international reserves with GDP to facilitate comparison across economies of different sizes. The variables in the $X_{i t}$ vector are a) the per capita GDP in logarithms, b) the average propensity to import given by the imports to GDP ratio, c) the exchange rate volatility measured by the standard deviation of monthly exchange rate data, d) the volatility of international reserve holding measured by the standard deviation of monthly data on international reserves, and e) the financial openness variable given by the sum of absolute values of capital inflow and outflow divided by GDP. The Taiwanese data were retrieved from the Central Bank of China (Taiwan) website and all other data were retrieved from the World Bank WDI and the IMF databases.

The Joneses effect is assessed using equations (21) and (22). The key issue is how to define the Joneses variable. We do not have a foolproof way to handle it because we do not have information on who are the Joneses. As a first attempt, we consider the Joneses variable $J_{i t}$ defined by

13 Some recent studies on the empirical international reserve demand behavior include Lane and Burke (2001), de Beaufort Wijnholds and Kapteyn (2001), Flood and Marion (2002), Aizenman and Marion (2003). Earlier studies are reviewed in, for example, Grubel (1971). 


$$
J_{i t}=\sum_{k \neq i} Y_{k t} .
$$

That is, all the other economies in the sample are the Joneses. Later, we consider a few alternative definitions of the Joneses variable.

Table 1: Demand for international reserves and the Joneses effect

\begin{tabular}{|c|c|c|c|}
\hline & Model (20) & Model (21) & Model (22) \\
\hline lngdppc & $\begin{array}{c}0.1437 * * * \\
(9.65)\end{array}$ & $\begin{array}{c}0.0605^{* * *} \\
(3.10)\end{array}$ & $\begin{array}{c}0.0682 * * * \\
(3.63)\end{array}$ \\
\hline $\mathrm{mp}$ & $\begin{array}{c}0.4374 \\
(1.08)\end{array}$ & $\begin{array}{c}0.0015 \\
(0.04)\end{array}$ & $\begin{array}{c}-0.0164 \\
(-0.41)\end{array}$ \\
\hline F_open & $\begin{array}{c}0.2105^{* * *} \\
(4.86)\end{array}$ & $\begin{array}{c}0.1704^{* * *} \\
\quad(4.20)\end{array}$ & $\begin{array}{c}0.1564 * * * \\
(4.01)\end{array}$ \\
\hline E_vol & $\begin{array}{c}0.0000^{* *} \\
(2.00)\end{array}$ & $\begin{array}{c}0.0000^{* *} \\
(2.22)\end{array}$ & $\begin{array}{c}0.0000 \\
(1.49)\end{array}$ \\
\hline R_vol & $\begin{array}{c}0.0025 * * * \\
\quad(3.72)\end{array}$ & $\begin{array}{c}0.0014^{* *} \\
(2.14)\end{array}$ & $\begin{array}{c}0.0010 \\
(1.60)\end{array}$ \\
\hline Joneses & & $\begin{array}{c}0.0681^{* * *} \\
\quad(6.27)\end{array}$ & $\begin{array}{c}0.0298 * * \\
(2.21)\end{array}$ \\
\hline $\mathrm{I}>97 *$ Joneses & & & $\begin{array}{c}0.0242^{* * *} \\
(4.45)\end{array}$ \\
\hline constant & $\begin{array}{c}-0.9794 * * * \\
(-8.73)\end{array}$ & $\begin{array}{c}-0.4236^{* * *} \\
(-3.03)\end{array}$ & $\begin{array}{c}-0.4206^{* * *} \\
(-3.14)\end{array}$ \\
\hline Adj. R-squares & 0.5561 & 0.6211 & 0.6535 \\
\hline Observations & 235 & 228 & 228 \\
\hline
\end{tabular}

Note: The table reports the results of estimating models (20) to (22) in the text using the panel data technique. "Ingdppc" is $\log$ per capita GDP, "mp" is propensity to import, "F_open" is financial openness, "E_vol" is exchange volatility, and "R_vol" is international reserve volatility. "Joneses" is the Joneses variable defined by equation (23) in the text. "I>97*Joneses" is the interactive Joneses variable $\mathrm{I}(\mathrm{t}-1>97)^{*} J_{i, t-1}$. T-statistics are in parentheses. “***” and “**” denote significance at the $1 \%$ and $5 \%$ levels, respectively.

\subsection{Panel Data Results}

The results of estimating (20) to (22) using the panel data technique are presented in Table 1. Under specification (20), in the absence of Joneses variables, most of the traditional 
factors in $X_{i t}$ are significant. The per capita output is a measure of the level of development and is significantly positive - a result similar to the one reported in Lane and Burke (2001). The import propensity is the average (rather than marginal) propensity. Thus, it is a proxy for trade openness and the degree of vulnerability to external shocks and has the expected positive coefficient (Frenkel, 1974). ${ }^{14}$

The effect of financial openness on the holding of international reserves is similar to the one of trade openness - a high level of openness increases an economy's vulnerability to external shocks. Even though both openness variables have a positive coefficient estimate, only the financial openness estimate is statistically significant. A similar financial openness effect is reported in, for example, Flood and Marion (2002). Frenkel and Jovanovic (1981) illustrate the effect of international reserve volatility in a stochastic inventory control setting. ${ }^{15}$ The estimation result is in accordance with the positive impact of international reserve volatility on hoarding of international reserves. Similarly, the international reserve holding is found to be negatively affected by exchange rate volatility.

Overall, these five variables explain the international reserve behavior quite well - in total they explain $56 \%$ of the variation in international reserve holdings of these 10 economies.

Estimation results pertaining to specifications (21) and (22) buttress the presence of keeping up with the Joneses effect among these East Asian economies between 1980 and 2004. Under specification (21), the coefficient estimate of the Joneses variable is highly significant with a value of 0.068 . In addition to statistical significance, the Joneses effect is of practical relevance. According to the estimate, a dollar increase in the international reserves held by one economy will lead to an increase of about .6 dollar by the other nine "peer economies." The inclusion of the Joneses variable lifts the adjusted R-squares from 56\% to 62\%. Compared with the results of (20), the coefficient estimates of the traditional explanatory variables are smaller and have a lower level of significance in the presence of the Joneses variable.

14 In contrast to Frenkel, Heller (1966) predicts a negative theoretical relation between propensity to import and the level of international reserves based on the argument that the higher the propensity to import $(\mathrm{m})$, the smaller marginal costs of balance of payments adjustment (i.e., $1 / m)$, and the weaker the demand for international reserves.

15 A similar model, which is the stochastic version of the one developed by Baumol (1952) and Tobin (1956), is used by Frenkel and Jovanovic (1980) to model cash holding. 
The interactive term I(t-1 > 97)* $J_{i, t-1}$ in specification (22) is positively significant along side with the Joneses variable $J_{i, t-1}$. The Joneses effect is not unique to the post-1997 crisis period but it is stronger after the East Asian financial crisis. The inclusion of the interactive Joneses term nonetheless lowers the impact of the original Joneses variable. It also weakens the significance of the traditional explanatory variables with the exception of the per capita output. Indeed, with both the Joneses variable and its interactive term, the per capita output and the financial openness are the only two traditional explanatory variables that are significant at the $5 \%$ level.

The coefficient estimate of the interactive term is quite comparable to that of the Joneses variable - suggesting that the keeping up with the Joneses effect is amplified quite noticeably after the Asian financial crises. The two estimates indicate that, with a dollar increase in one economy's holding of international reserves, the other peer economies will boost their international reserves by slightly less than .3 dollar before the crisis but by slightly larger than .5 dollar after the crisis. The strengthening of the effect appears in accordance with the anecdotal evidence mentioned in the introduction. Apparently, the dramatic adverse effect of the crisis sways policymaker's behavior and makes them be more strategic in positioning their holdings of international reserves among their peers. An interesting observation is the presence of the keeping up with the Joneses effect even before the crisis.

One uncertainty is that we do not know, from these economies' point of view, who are their Joneses. Equation (23) implicitly asserts that all the economies in the sample are the Joneses. To check the robustness of the estimation results, we consider an alternative specification of the Joneses variable. Instead of trying all the possible combinations, we reckon the possibility that an economy may identify just a few representatives in the region as the Joneses. Such a strategy may be justified by monitoring costs and by the belief that the representative economies have timely information and have good assessment of the regional economic conditions.

Thus, to investigate the robustness of the results, we consider the Joneses variable comprises international reserve data from only China, Japan, Korea, and Taiwan; that is

$$
J_{i t}=\Sigma_{k=\text { China, Japan, Korea, and Taiwan }} Y_{k t} \text {. }
$$


These four are arguably the major economies in the region. For any one of these four economies, the Joneses variable is defined to be the sum of the other three economies' international reserves. The estimation results based on the alternative definition of the Joneses variable are presented in Table 2.

Table 2: Demand for international reserves with an alternative definition of the Joneses variable

\begin{tabular}{ccc}
\hline & Model (21) & Model (22) \\
\hline lngdppc & $0.1107^{* * *}$ & $0.0905^{* * *}$ \\
mp & $(6.72)$ & $(5.82)$ \\
& 0.0474 & 0.0068 \\
F_open & $(1.15)$ & $(0.18)$ \\
& $0.0846^{* *}$ & $0.0598^{*}$ \\
E_vol & $(2.57)$ & $(1.95)$ \\
& $0.0000^{* *}$ & 0.0000 \\
R_vol & $(2.13)$ & $(1.36)$ \\
& $0.0016^{* *}$ & 0.0009 \\
Joneses_4 & $(2.40)$ & $(1.40)$ \\
& $0.1173^{* * *}$ & $0.0372^{*}$ \\
I>97*Joneses_4 & $(6.10)$ & $(1.70)$ \\
& & $0.0946^{* * *}$ \\
constant & $(-6.27)$ & $(6.25)$ \\
Adj. R-squares & 0.5867 & $-0.5593^{* * *}$ \\
Observations & 228 & $(-4.75)$ \\
\hline
\end{tabular}

Note: The table reports the panel regression results of models (21) and (22) in the text. "Ingdppc” is log per capita GDP, “mp” is propensity to import, "F_open” is financial openness, "E_vol” is exchange volatility, and "R_vol” is international reserve volatility. "Joneses_4” is the Joneses variable defined by equation (24) in the text.

“I>97*Joneses_4” is the interactive Joneses variable $\mathrm{I}(\mathrm{t}-1>97) * J_{i, t-1} . \mathrm{t}$-statistics are in parentheses. “***”, “**”, and “*” denote significance at the $1 \%, 5 \%$ and $10 \%$ level, respectively.

Compared with Table 1, the Joneses effect based on the four-economy specification is stronger. For the whole sample estimation, the Joneses variable coefficient is 0.117 in Table 2 
versus 0.068 in Table 1. Since only four economies in the sample contribute to the Joneses effect, the pattern of response to an increase in international reserves is slightly different from the one obtained from Table 1 . Specifically, the response will be relatively strong in the first period and be relatively moderate in the subsequent periods. To gauge the magnitude of the Joneses effect in this setting, we consider the case in which one of the four Joneses economies increases its international reserves by one dollar. The increase of total international reserves in the first period is slightly over one dollar. In the second period, the total international reserves move up by a moderate amount of .4 dollar.

Apparently, the significance of the four-economy Joneses variable is mainly driven by its effect in the post-crisis period. The Joneses variable $J_{i, t-1}$ is significant only at the $10 \%$ but not at the $5 \%$ level in the presence of the significant interaction term I(t-1>97)* $J_{i, t-1}$.

In terms of overall explanatory power, the two specifications with a four-economy Joneses variable have adjusted R-squares estimate slightly lower than those reported in Table 1. Even though the pattern of the Joneses effect changes as we modify the way to construct the Joneses variable, the change appears to be a matter of magnitude rather than of the nature of the effect. Specifically, both Joneses variables indicate the Joneses effect is stronger in the post-crisis period.

\subsection{Economy-By-Economy Results}

The panel regression technique adopted in Tables 1 and 2 improves estimation efficiency by pooling data across economies. However, the technique restricts the economies to display same responses to explanatory variables. The restriction may not be appropriate for a diverse group of economies. An alternative approach is to use the data from individual economies to estimate the international reserve demand equations. Such an approach offers only 24 or less observations per economy but allows us to explore economy-specific behavior and its possible implications for the Joneses effect. Recognizing the small sample size we are working with, we report the estimation results for individual economies in Table 3.

The economy-by-economy results without the Joneses variable are presented in Table 3.a. It is evident that the coefficient estimates are heterogeneous across individual economies. There are both similarities and differences between these results and those from Model (20) reported in Table 1. 
Table 3.a: Results from individual economies without the Joneses effect

\begin{tabular}{ccccccccccc}
\hline & China & India & Indonesia & Japan & Korea & Malaysia & Philippines & Singapore & Taiwan & Thailand \\
\hline \multirow{2}{*}{ lngdppc } & $0.1151^{* * *}$ & 0.0161 & 0.0309 & $0.1344^{* * *}$ & $0.1184^{* * *}$ & 0.1246 & -0.0515 & $0.2902^{* *}$ & $-0.4402^{* * *}$ & $0.1468^{* * *}$ \\
& $(3.69)$ & $(0.65)$ & $(1.02)$ & $(3.00)$ & $(5.15)$ & $(1.07)$ & $(-0.65)$ & $(2.63)$ & $(-3.36)$ & $(4.12)$ \\
& $-0.5428^{*}$ & $0.9984^{* * *}$ & $0.5418^{*}$ & $0.9556^{* * *}$ & $0.9602^{* * *}$ & 0.0685 & $0.4353^{* * *}$ & -0.1026 & $1.7498^{* * *}$ & $0.3930^{* * *}$ \\
mp & $(-1.97)$ & $(3.42)$ & $(1.94)$ & $(3.78)$ & $(4.32)$ & $(0.43)$ & $(6.97)$ & $(-0.99)$ & $(3.74)$ & $(3.94)$ \\
& -0.1363 & -0.1487 & $-1.3096^{* * *}$ & 0.0803 & -0.3103 & -0.1262 & $0.1400^{* * *}$ & -0.0764 & 0.3525 & $0.2376^{* *}$ \\
F_open & $(-0.41)$ & $(-0.53)$ & $(-2.90)$ & $(0.62)$ & $(-1.65)$ & $(-0.64)$ & $(3.56)$ & $(-1.10)$ & $(0.83)$ & $(1.97)$ \\
& -0.0253 & -0.0053 & $0.0001^{* *}$ & -0.0008 & $-0.0004^{* * *}$ & $-0.2740^{* * *}$ & $-0.0093^{* *}$ & -0.5536 & -0.0136 & -0.0023 \\
E_vol & $(-0.35)$ & $(-1.48)$ & $(2.78)$ & $(-0.74)$ & $(-3.92)$ & $(-3.18)$ & $(-2.51)$ & $(-0.75)$ & $(-0.45)$ & $(-0.60)$ \\
& $0.0046^{* * *}$ & $0.0106^{* * *}$ & -0.0023 & $0.0017 * * *$ & $0.0117^{* * *}$ & $0.0431^{* * *}$ & -0.0110 & $0.0338^{*}$ & $0.0165^{* *}$ & $-0.0130^{* *}$ \\
R_vol & $(5.43)$ & $(6.22)$ & $(-0.13)$ & $(4.39)$ & $(4.66)$ & $(3.73)$ & $(-0.63)$ & $(1.81)$ & $(2.97)$ & $(-1.98)$ \\
& $-0.5492^{* * *}$ & -0.1399 & -0.1707 & $-1.4426^{* * *}$ & $-1.2295^{* * *}$ & -0.8032 & 0.2928 & -1.8721 & $3.7644^{* * *}$ & $-1.0589 * * *$ \\
constant & $(-3.43)$ & $(-1.16)$ & $(-0.99)$ & $(-3.01)$ & $(-5.04)$ & $(-0.97)$ & $(0.55)$ & $(-1.64)$ & $(3.33)$ & $(-4.81)$ \\
Adj R-squares & 0.9152 & 0.9176 & 0.8244 & 0.8008 & 0.9192 & 0.7958 & 0.8893 & 0.8346 & 0.8432 & 0.9465 \\
Observations & 23 & 24 & 24 & 25 & 25 & 24 & 25 & 25 & 15 & 25 \\
\hline
\end{tabular}

Note: The table reports the results of estimating model (20) economy by economy. "Ingdppc” is log per capita GDP, “mp” is propensity to import, "F_open” is financial openness, "E_vol” is exchange volatility, and "R_vol” is international reserve volatility. t-statistics are in parentheses. “***”, “**”, and “*” denote significance at the $1 \%, 5 \%$ and $10 \%$ level, respectively. 
Table 3.b: Results from individual economies with the Joneses effect

\begin{tabular}{|c|c|c|c|c|c|c|c|c|c|c|}
\hline & China & India & Indonesia & Japan & Korea & Malaysia & Philippines & Singapore & Taiwan & Thailand \\
\hline lngdppc & $\begin{array}{c}0.1226^{* * *} \\
(2.91)\end{array}$ & $\begin{array}{l}0.0448 \\
(0.69)\end{array}$ & $\begin{array}{c}-0.0378 \\
(-1.02)\end{array}$ & $\begin{array}{c}-0.0150 \\
(-0.37)\end{array}$ & $\begin{array}{c}0.1379 * * * \\
(3.07)\end{array}$ & $\begin{array}{l}-0.0112 \\
(-0.07)\end{array}$ & $\begin{array}{c}-0.0647 \\
(-0.74)\end{array}$ & $\begin{array}{l}-0.0112 \\
(-0.10)\end{array}$ & $\begin{array}{c}-0.5494 * * \\
(-2.78)\end{array}$ & $\begin{array}{c}0.0994 * * \\
(2.64)\end{array}$ \\
\hline $\mathrm{mp}$ & $\begin{array}{c}-0.4901 \\
(-1.44)\end{array}$ & $\begin{array}{c}0.7831 * \\
(1.74)\end{array}$ & $\begin{array}{c}0.4269 * \\
(1.73)\end{array}$ & $\begin{array}{c}0.8716^{* * *} \\
(4.97)\end{array}$ & $\begin{array}{c}0.9513^{* * *} \\
(4.12)\end{array}$ & $\begin{array}{c}0.1228 \\
(0.73)\end{array}$ & $\begin{array}{c}0.4054 * * * \\
(3.52)\end{array}$ & $\begin{array}{c}-0.2803^{* * *} \\
(-2.95)\end{array}$ & $\begin{array}{c}1.5215^{* *} \\
(2.69)\end{array}$ & $\begin{array}{l}0.1891 \\
(1.71)\end{array}$ \\
\hline F_open & $\begin{array}{c}-0.1901 \\
(-0.48)\end{array}$ & $\begin{array}{c}-0.2066 \\
(-0.61)\end{array}$ & $\begin{array}{l}-0.6230 \\
(-1.32)\end{array}$ & $\begin{array}{l}0.0067 \\
(0.08)\end{array}$ & $\begin{array}{c}-0.4761^{* *} \\
(-2.21)\end{array}$ & $\begin{array}{c}-0.0081 \\
(-0.04)\end{array}$ & $\begin{array}{c}0.1348^{* * *} \\
(3.44)\end{array}$ & $\begin{array}{c}-0.0581 \\
(-1.11)\end{array}$ & $\begin{array}{l}0.1661 \\
(0.33)\end{array}$ & $\begin{array}{c}0.4562 * * * \\
(3.61)\end{array}$ \\
\hline E_vol & $\begin{array}{l}-0.0336 \\
(-0.42)\end{array}$ & $\begin{array}{l}-0.0054 \\
(-1.45)\end{array}$ & $\begin{array}{c}0.0001^{* * *} \\
(3.17)\end{array}$ & $\begin{array}{l}0.0006 \\
(0.76)\end{array}$ & $\begin{array}{c}-0.0004^{* * *} \\
(-3.6)\end{array}$ & $\begin{array}{c}-0.1813^{*} \\
(-1.77)\end{array}$ & $\begin{array}{c}-0.0075^{*} \\
(-1.74)\end{array}$ & $\begin{array}{c}-0.1226 \\
(-0.21)\end{array}$ & $\begin{array}{l}-0.0095 \\
(-0.30)\end{array}$ & $\begin{array}{l}-0.0037 \\
(-1.13)\end{array}$ \\
\hline R_vol & $\begin{array}{c}0.0046^{* * *} \\
(5.14)\end{array}$ & $\begin{array}{c}0.0110^{* * *} \\
(5.39)\end{array}$ & $\begin{array}{c}-0.0058 \\
(-0.37)\end{array}$ & $\begin{array}{l}0.0005 \\
(1.44)\end{array}$ & $\begin{array}{c}0.0114^{* * * *} \\
(4.26)\end{array}$ & $\begin{array}{c}0.0401^{* * *} \\
(3.49)\end{array}$ & $\begin{array}{c}-0.0063 \\
(-0.33)\end{array}$ & $\begin{array}{c}0.0349 * * \\
(2.49)\end{array}$ & $\begin{array}{c}0.0146 * * \\
(2.36)\end{array}$ & $\begin{array}{c}-0.0128 * * \\
(-2.27)\end{array}$ \\
\hline Joneses & $\begin{array}{c}-0.0101 \\
(-0.28)\end{array}$ & $\begin{array}{l}-0.0055 \\
(-0.32)\end{array}$ & $\begin{array}{c}0.0410^{* * *} \\
(2.63)\end{array}$ & $\begin{array}{c}0.0619 * * * \\
(5.21)\end{array}$ & $\begin{array}{c}-0.0049 \\
(-0.17)\end{array}$ & $\begin{array}{l}0.0647 \\
(1.63)\end{array}$ & $\begin{array}{l}0.0073 \\
(0.52)\end{array}$ & $\begin{array}{c}0.1538 * * * \\
(3.97)\end{array}$ & $\begin{array}{l}0.0808 \\
(0.75)\end{array}$ & $\begin{array}{c}0.0576 * * * \\
(3.15)\end{array}$ \\
\hline constant & $\begin{array}{c}-0.5820^{* *} \\
(-2.87)\end{array}$ & $\begin{array}{c}-0.2766 \\
(-0.9)\end{array}$ & $\begin{array}{l}0.1907 \\
(0.94)\end{array}$ & $\begin{array}{c}0.0035 \\
(0.01)\end{array}$ & $\begin{array}{c}-1.3804^{* * *} \\
(-3.54)\end{array}$ & $\begin{array}{l}0.1150 \\
(0.11)\end{array}$ & $\begin{array}{c}0.3743 \\
(0.64)\end{array}$ & $\begin{array}{l}1.0855 \\
(0.97)\end{array}$ & $\begin{array}{c}4.7485^{* *} \\
(2.72)\end{array}$ & $\begin{array}{c}-0.7645^{* * *} \\
(-3.27)\end{array}$ \\
\hline Adj R-squares & 0.9103 & 0.9142 & 0.8678 & 0.9193 & 0.9265 & 0.8094 & 0.8957 & 0.902 & 0.8353 & 0.9612 \\
\hline Observations & 23 & 23 & 24 & 24 & 24 & 23 & 24 & 24 & 15 & 24 \\
\hline
\end{tabular}

Note: The table reports the results of estimating model (21) economy by economy. "Ingdppc” is log per capita GDP, “mp” is propensity to import, "F_open" is financial openness, "E-vol” is exchange volatility, and "R_vol” is international reserve volatility. "Joneses" is the Joneses variable defined by equation (23) in the text. t-statistics are in parentheses. “***”, “**”, and “*” denote significance at the $1 \%, 5 \%$ and $10 \%$ level, respectively. 
Table 3.c: Results for individual economies with period-specified Joneses effects

\begin{tabular}{|c|c|c|c|c|c|c|c|c|c|c|}
\hline & China & India & Indonesia & Japan & Korea & Malaysia & Philippines & Singapore & Taiwan & Thailand \\
\hline lngdppc & $\begin{array}{c}0.0902 * * \\
(2.53)\end{array}$ & $\begin{array}{l}-0.0198 \\
(-0.37)\end{array}$ & $\begin{array}{l}0.0389 \\
(1.12)\end{array}$ & $\begin{array}{l}-0.0176 \\
(-0.42)\end{array}$ & $\begin{array}{c}0.0437 \\
(1.35)\end{array}$ & $\begin{array}{c}-0.0756 \\
(-0.5)\end{array}$ & $\begin{array}{c}-0.1240 * \\
(-1.75)\end{array}$ & $\begin{array}{l}-0.0050 \\
(-0.04)\end{array}$ & $\begin{array}{c}-0.8913^{* * *} \\
(-3.96)\end{array}$ & $\begin{array}{c}0.1692 * * * \\
(6.25)\end{array}$ \\
\hline $\mathrm{mp}$ & $\begin{array}{l}-0.2494 \\
(-0.87)\end{array}$ & $\begin{array}{c}0.6319 * \\
(1.79)\end{array}$ & $\begin{array}{l}0.2958 \\
(1.57)\end{array}$ & $\begin{array}{c}0.7775^{* * *} \\
(3.56)\end{array}$ & $\begin{array}{l}0.2596 \\
(1.37)\end{array}$ & $\begin{array}{c}0.1877 \\
(1.15)\end{array}$ & $\begin{array}{c}0.3196 * * * \\
(3.40)\end{array}$ & $\begin{array}{c}-0.2686 * * \\
(-2.71)\end{array}$ & $\begin{array}{c}1.3437 * * \\
(2.84)\end{array}$ & $\begin{array}{l}0.0408 \\
(0.54)\end{array}$ \\
\hline F_open & $\begin{array}{l}-0.0822 \\
(-0.26)\end{array}$ & $\begin{array}{l}0.3899 \\
(1.24)\end{array}$ & $\begin{array}{l}-0.1483 \\
(-0.39)\end{array}$ & $\begin{array}{c}-0.0044 \\
(-0.05)\end{array}$ & $\begin{array}{l}-0.1095 \\
(-0.74)\end{array}$ & $\begin{array}{l}-0.1070 \\
(-0.53)\end{array}$ & $\begin{array}{c}0.0776^{* *} \\
(2.21)\end{array}$ & $\begin{array}{l}-0.0566 \\
(-1.05)\end{array}$ & $\begin{array}{c}0.1978 \\
(0.48)\end{array}$ & $\begin{array}{c}0.2949 * * * \\
(3.47)\end{array}$ \\
\hline E_vol & $\begin{array}{c}-0.0369 \\
(-0.57)\end{array}$ & $\begin{array}{c}-0.0023 \\
(-0.75)\end{array}$ & $\begin{array}{c}0.0000 * * \\
(2.32)\end{array}$ & $\begin{array}{l}0.0004 \\
(0.53)\end{array}$ & $\begin{array}{c}-0.0002^{* *} \\
(-2.49)\end{array}$ & $\begin{array}{l}-0.1575 \\
(-1.61)\end{array}$ & $\begin{array}{c}-0.0062 * \\
(-1.81)\end{array}$ & $\begin{array}{l}-0.1682 \\
(-0.28)\end{array}$ & $\begin{array}{c}0.1055 \\
(1.81)\end{array}$ & $\begin{array}{c}-0.0085 * * * \\
(-3.75)\end{array}$ \\
\hline R_vol & $\begin{array}{c}0.0040 * * * \\
(5.29)\end{array}$ & $\begin{array}{c}0.0098 * * * \\
(6.05)\end{array}$ & $\begin{array}{c}-0.0133 \\
(-1.10)\end{array}$ & $\begin{array}{l}0.0005 \\
(1.33)\end{array}$ & $\begin{array}{c}0.0045^{* *} \\
(2.19)\end{array}$ & $\begin{array}{c}0.0472 * * * \\
(4.06)\end{array}$ & $\begin{array}{l}0.0226 \\
(1.32)\end{array}$ & $\begin{array}{c}0.0374^{* *} \\
(2.49)\end{array}$ & $\begin{array}{c}0.0127^{* *} \\
(2.46)\end{array}$ & $\begin{array}{l}-0.0007 \\
(-0.18)\end{array}$ \\
\hline Joneses & $\begin{array}{c}-0.0343 \\
(-1.12)\end{array}$ & $\begin{array}{l}-0.0019 \\
(-0.14)\end{array}$ & $\begin{array}{c}-0.0155 \\
(-0.81)\end{array}$ & $\begin{array}{c}0.0556 * * * \\
(3.76)\end{array}$ & $\begin{array}{l}0.0104 \\
(0.60)\end{array}$ & $\begin{array}{c}0.0274 \\
(0.63)\end{array}$ & $\begin{array}{l}-0.0104 \\
(-0.84)\end{array}$ & $\begin{array}{c}0.1292 * * \\
(2.16)\end{array}$ & $\begin{array}{c}0.4535^{* *} \\
(2.37)\end{array}$ & $\begin{array}{c}-0.0063 \\
(-0.37)\end{array}$ \\
\hline I $>97 *$ Joneses & $\begin{array}{c}0.0212^{* * *} \\
(3.07)\end{array}$ & $\begin{array}{c}0.0130 * * * \\
(3.39)\end{array}$ & $\begin{array}{c}0.0278 * * * \\
(3.73)\end{array}$ & $\begin{array}{c}0.0038 \\
(0.74)\end{array}$ & $\begin{array}{c}0.0387 * * * \\
(5.46)\end{array}$ & $\begin{array}{l}0.0244 \\
(1.71)\end{array}$ & $\begin{array}{c}0.0222 * * * \\
(3.39)\end{array}$ & $\begin{array}{c}0.0128 \\
(0.55)\end{array}$ & $\begin{array}{c}-0.1242^{*} \\
(-2.2)\end{array}$ & $\begin{array}{c}0.0290 * * * \\
(5.23)\end{array}$ \\
\hline constant & $\begin{array}{c}-0.3878 * * \\
(-2.21)\end{array}$ & $\begin{array}{l}0.0808 \\
(0.31)\end{array}$ & $\begin{array}{l}-0.2013 \\
(-1.08)\end{array}$ & $\begin{array}{l}0.0494 \\
(0.12)\end{array}$ & $\begin{array}{l}-0.4172 \\
(-1.41)\end{array}$ & $\begin{array}{c}0.6339 \\
(0.59)\end{array}$ & $\begin{array}{l}0.8179 \\
(1.71)\end{array}$ & $\begin{array}{l}1.0279 \\
(0.90)\end{array}$ & $\begin{array}{c}7.3576^{* * *} \\
(3.95)\end{array}$ & $\begin{array}{c}-1.1135 * * * \\
(-6.91)\end{array}$ \\
\hline Adj. R-squares & 0.9413 & 0.9482 & 0.9249 & 0.9171 & 0.9727 & 0.8299 & 0.9355 & 0.8978 & 0.8886 & 0.9848 \\
\hline Observations & 23 & 23 & 24 & 24 & 24 & 23 & 24 & 24 & 15 & 24 \\
\hline
\end{tabular}

Note: The table reports the results of estimating model (22) economy by economy. "Ingdppc” is the log per capita GDP, "mp” is the import propensity, “F_open” is financial openness, “E_vol” is exchange volatility, and "R_vol” is international reserve volatility. “Joneses” is the Joneses variable defined by equation (23) in the text. "I $>97 *$ Joneses" is the interactive Joneses variable I(t-1>97)* $J_{i, t-1}$. t-statistics are in parentheses. “***”, “**”, and “*” denote significance at the $1 \%, 5 \%$ and $10 \%$ level, respectively. 
For instance, the per capita output, propensity to import, and international reserve volatility variables are usually positive though not all of them are significant. Compared with the panel regression results, the per capita output is less likely to be significant - five out of ten estimates are significantly positive. Taiwan, on the other hand, displays a significantly negative output effect on international reserve accumulation. The propensity to import variable is significantly positive in seven of the ten cases. China, interestingly, has a negative propensity to import effect on international reserve hoarding. The effect of financial openness is weaker than that of trade openness. It is also weaker than the financial openness effect reported in Table 1. The individual exchange rate volatility effects also appear different from those under the panel specification.

One general observation is that the explanatory power recorded in Table 3.a is higher than the one under the panel specification. The adjusted R-squares estimates in Table 3.a are $80 \%$ or higher. The accommodation of economy-specific behavior gives a better fit to the data, even though the small sample size (relative to the number of regressors) may have "inflated" the goodness of fit measure.

The effects of the Joneses and the interactive Joneses variables are presented in Tables 3.b and 3.c. Apparently, the per capita output is affected the most by the presence of the added variables. In Table 3.b, seven of the ten Joneses coefficient estimates are positive and four of them are statistically significant. The Joneses effect seems quite prevalent in the aftermath of the 1997 crisis - the interactive Joneses variable has a positive coefficient estimate in nine of the ten cases reported in Table 3.c and six of these nine positive estimates are significant. It is also noted that the coefficient estimate of the Taiwanese interactive Joneses variable is significantly negative.

In the presence of the interactive variable, the Joneses variable is significantly positive for three economies; namely Japan, Singapore, and Taiwan. In the case of Taiwan, the negative interactive Joneses effect is weaker than the Joneses effect. There is still the Joneses effect in the post crisis period. However, unlike other economies, the Joneses effect experienced by Taiwan in the post-crisis period is weaker, instead of stronger. With Taiwan as the only exception, the results indicate that the Joneses effect is more prominent after 1997. 
Table 4.a: Results from individual economies with the an alternative definition of the Joneses effect

\begin{tabular}{cccccccccccc}
\hline & China & India & Indonesia & Japan & Korea & Malaysia & Philippines & Singapore & Taiwan & Thailand \\
\hline \multirow{2}{*}{ Ingdppc } & $0.1206^{* * *}$ & 0.0458 & 0.0099 & $0.0954^{* * *}$ & $0.1414^{* * *}$ & 0.0952 & -0.0795 & 0.1547 & $-0.4842^{* * *}$ & $0.1363^{* * *}$ \\
& $(3.6)$ & $(0.86)$ & $(0.30)$ & $(3.20)$ & $(5.85)$ & $(0.68)$ & $(-0.92)$ & $(1.53)$ & $(-3.46)$ & $(3.23)$ \\
& -0.4710 & 0.6770 & $0.5163^{*}$ & $1.1368^{* * *}$ & $0.9141^{* * *}$ & 0.0851 & $0.4507^{* * *}$ & $-0.2172^{* *}$ & 1.1941 & $0.3219^{* *}$ \\
mp & $(-1.51)$ & $(1.19)$ & $(1.90)$ & $(6.55)$ & $(4.38)$ & $(0.49)$ & $(4.61)$ & $(-2.15)$ & $(1.59)$ & $(2.64)$ \\
& -0.2622 & -0.1935 & $-0.9746^{*}$ & -0.0042 & $-0.5639^{* *}$ & -0.0205 & $0.1351^{* * *}$ & -0.0540 & 0.1026 & $0.3339^{* *}$ \\
F_open & $(-0.63)$ & $(-0.36)$ & $(-1.95)$ & $(-0.05)$ & $(-2.66)$ & $(-0.09)$ & $(3.32)$ & $(-0.92)$ & $(0.21)$ & $(2.26)$ \\
& -0.0317 & -0.0054 & $0.0001^{* *}$ & 0.0001 & $-0.0004^{* * *}$ & $-0.2356^{* *}$ & $-0.0085^{*}$ & -0.3432 & -0.0235 & -0.0026 \\
E_vol & $(-0.42)$ & $(-1.46)$ & $(2.78)$ & $(0.19)$ & $(-4.37)$ & $(-2.37)$ & $(-2.00)$ & $(-0.54)$ & $(-0.74)$ & $(-0.66)$ \\
& $0.0046^{* * *}$ & $0.0113^{* * *}$ & -0.0048 & $0.0010^{* * *}$ & $0.0125^{* * *}$ & $0.0406^{* * *}$ & -0.0097 & $0.0301^{*}$ & 0.0126 & $-0.0135^{*}$ \\
R_vol & $(5.28)$ & $(4.87)$ & $(-0.27)$ & $(3.47)$ & $(4.80)$ & $(3.35)$ & $(-0.49)$ & $(1.92)$ & $(1.81)$ & $(-2.00)$ \\
& -0.0278 & -0.0122 & 0.0379 & $0.0886^{* * *}$ & -0.0388 & 0.0536 & 0.0014 & $0.1686^{* * *}$ & 0.3376 & 0.0400 \\
Joneses_4 & $(-0.54)$ & $(-0.44)$ & $(1.41)$ & $(5.24)$ & $(-1.15)$ & $(0.89)$ & $(0.06)$ & $(3.09)$ & $(0.95)$ & $(1.28)$ \\
& $-0.5737 * * *$ & -0.2777 & -0.0654 & $-1.0950^{* * *}$ & $-1.3863^{* * *}$ & -0.6238 & 0.4765 & -0.5079 & $4.3506^{* * *}$ & $-0.9898^{* * *}$ \\
constant & $(-3.38)$ & $(-1.11)$ & $(-0.36)$ & $(-3.47)$ & $(-5.81)$ & $(-0.63)$ & $(0.82)$ & $(-0.49)$ & $(3.37)$ & $(-3.76)$ \\
Adj. R-squares & 0.9115 & 0.9146 & 0.8337 & 0.9198 & 0.9317 & 0.7883 & 0.8941 & 0.8791 & 0.8415 & 0.9439 \\
Observations & 23 & 23 & 24 & 24 & 24 & 23 & 24 & 24 & 15 & 24 \\
\hline
\end{tabular}

Note: The table reports the results of estimating model (22) economy by economy. “Ingdppc” is log per capita GDP, “mp” is propensity to import, "F_open" is financial openness, "E-vol” is exchange volatility, and "R_vol” is international reserve volatility. "Joneses_4" is the Joneses variable defined by equation (24) in the text. t-statistics are in parentheses. “***”, “**”, and “*” denote significance at the $1 \%$, $5 \%$ and $10 \%$ level, respectively. 
Table 4.b: Results for individual economies with an alternative definition of period-specified Joneses effects

\begin{tabular}{|c|c|c|c|c|c|c|c|c|c|c|}
\hline & China & India & Indonesia & Japan & Korea & Malaysia & Philippines & Singapore & Taiwan & Thailand \\
\hline \multirow{2}{*}{ lngdppc } & $0.0784 * *$ & 0.0272 & 0.0207 & 0.0462 & $0.0521 * *$ & -0.0346 & $-0.1780 * *$ & 0.1180 & $-0.4856 * *$ & $0.1656 * * *$ \\
\hline & $(2.54)$ & $(0.69)$ & $(0.79)$ & $(1.70)$ & $(2.56)$ & $(-0.23)$ & $(-2.74)$ & $(1.20)$ & $(-3.21)$ & (6.66) \\
\hline \multirow{2}{*}{$\mathrm{mp}$} & -0.3807 & 0.1423 & 0.3919* & $0.6730 * * *$ & 0.0991 & 0.1851 & $0.3281 * * *$ & $-0.2167 * *$ & 1.1875 & 0.0447 \\
\hline & $(-1.48)$ & $(0.33)$ & (1.79) & (3.54) & $(0.55)$ & (1.08) & (4.39) & $(-2.26)$ & $(1.47)$ & $(0.53)$ \\
\hline \multirow{2}{*}{ F_open } & -0.0385 & 0.3174 & -0.3400 & -0.0407 & -0.1015 & -0.1010 & $0.0879 * *$ & -0.0566 & 0.1075 & $0.3684 * * *$ \\
\hline & $(-0.11)$ & $(1.23)$ & $(-0.78)$ & $(-0.61)$ & $(-0.70)$ & $(-0.47)$ & $(2.85)$ & $(-1.02)$ & $(0.20)$ & $(4.30)$ \\
\hline \multirow{2}{*}{ E_vol } & -0.0164 & -0.0028 & $0.0000 * * *$ & -0.0001 & -0.0001 & $-0.1765^{*}$ & $-0.0060 *$ & -0.3209 & -0.0220 & $-0.0080 * * *$ \\
\hline & $(-0.27)$ & $(-1.01)$ & $(2.49)$ & $(-0.20)$ & $(-1.60)$ & $(-1.80)$ & $(-1.95)$ & $(-0.53)$ & $(-0.51)$ & $(-3.28)$ \\
\hline \multirow{2}{*}{ R_vol } & $0.0037 * * *$ & $0.0098^{* * *}$ & -0.0148 & $0.0006^{* *}$ & -0.0007 & $0.0462 * * *$ & 0.0192 & $0.0336 * *$ & 0.0125 & -0.0042 \\
\hline & $(4.71)$ & $(5.62)$ & $(-1.03)$ & $(2.31)$ & $(-0.26)$ & (3.95) & $(1.23)$ & $(2.24)$ & (1.69) & $(-1.00)$ \\
\hline \multirow{2}{*}{ Joneses_4 } & -0.0323 & -0.0328 & -0.0166 & $0.0606 * * *$ & -0.0075 & 0.0180 & $-0.0447 * *$ & $0.1089 *$ & 0.3678 & -0.0089 \\
\hline & $(-0.77)$ & $(-1.57)$ & $(-0.62)$ & (3.92) & $(-0.37)$ & $(0.30)$ & $(-2.23)$ & $(1.74)$ & $(0.59)$ & $(-0.45)$ \\
\hline \multirow{2}{*}{ I>97*Joneses_4 } & $0.0816^{* * *}$ & $0.0480 * * *$ & $0.0624 * * *$ & $0.0461 * * *$ & $0.1978 * * *$ & $0.0717^{*}$ & $0.0760 * * *$ & 0.0660 & -0.0214 & $0.0771 * * *$ \\
\hline & $(2.97)$ & (3.87) & $(3.35)$ & $(3.47)$ & $(5.98)$ & $(1.85)$ & $(4.26)$ & $(1.70)$ & $(-0.06)$ & $(5.92)$ \\
\hline \multirow{2}{*}{ constant } & $-0.3433 * *$ & -0.1332 & -0.1090 & $-0.5321 *$ & $-0.4210^{*}$ & 0.3471 & $1.1900 * *$ & -0.1402 & $4.3600 * *$ & $-1.0978 * * *$ \\
\hline & $(-2.16)$ & $(-0.72)$ & $(-0.75)$ & $(-1.81)$ & $(-1.99)$ & $(0.33)$ & $(2.70)$ & $(-0.14)$ & $(3.14)$ & $(-7.17)$ \\
\hline Adj R-squares & 0.9406 & 0.9545 & 0.8961 & 0.9514 & 0.9776 & 0.8161 & 0.9474 & 0.8912 & 0.8189 & 0.9813 \\
\hline Observations & 23 & 23 & 24 & 24 & 24 & 23 & 24 & 24 & 15 & 24 \\
\hline
\end{tabular}

Note: The table reports the results of estimating model (22) economy by economy. "Ingdppc” is log per capita GDP, "mp” is propensity to import, "F_open" is financial openness, "E_vol” is exchange volatility, and "R_vol" is international reserve volatility. "Joneses_4" is the Joneses variable defined by equation (24) in the text. "I $>97^{*}$ Joneses_4” is the interactive Joneses variable I(t-1>97)* $J_{i, t-1}$. t-statistics are in parentheses. “***”, “**”, and “*” denote significance at the $1 \%, 5 \%$ and $10 \%$ level, respectively. 
The economy-by-economy results pertaining to the alternative definition of the Joneses variable are given in Tables 4.a and 4.b. A comparison of the coefficient estimates of the Joneses and the interactive Joneses variables leads to a similar observation - the Joneses effect is more prevalent and prominent in the post-1997 crisis sample. Specifically, eight of the ten interactive terms are significantly positive and only two Joneses variables are significant.

Although there are discernable differences in Tables 3.b, 3.c, 4.a, and 4.b, the performance of the two alternative specifications of the Joneses variables is quite comparable. The differences include the Joneses variable based on the four-economies specification is only significant in two cases in Table 4.a while it is significant in four cases in Table 3.b. On the other hand, the Joneses effect is stronger in the post crisis period with the four-economies Joneses specification. Similar to the panel data results, the regressions with the four-economies Joneses variable have adjusted R-squares estimates slightly less than those with the Joneses variable defined by all the economies in the sample. Nonetheless, these two sets of results are suggestive of the presence of the keeping up with the Joneses effect.

These regressions results, especially those allowing for economy-specific behavior, the selected variables (both the traditional macroeconomic variables and the two Joneses variables) explain the evolution of the holdings of international reserves quite well. To offer some insights on the debate of excessive international reserve hoarding, we examine the estimated residual that is given by the difference between the actual level of international reserve holdings and the level explained by the regressors. Thus, a positive estimated residual suggests that the actual holding level is higher than the one warranted by the model.

According to the argument, the Joneses effect will lead to a level of international reserves that is higher than the one implied by fundamentals alone. If the Joneses effect is in operation but it is not accounted for in the regression analysis, the observed international reserves will appear higher than they should be. Thus, with the Joneses effect, the predicted value of international reserve holding should be higher in the presence of Joneses variables than without them.

Figure 1 presents graphs of estimated residuals from the model with only traditional macroeconomic variables as regressors and from the model that also includes both the Joneses and the interactive Joneses variables. Since the inclusion of the Joneses variables tend to improve the goodness of the fit, it is not surprising to observe that estimated residuals from the model allowing for the Joneses effect are in general smaller than those from the model without the 
Joneses variable. Another way to interpret the result is that the incorporation of the Joneses effect makes the observed international reserve holdings closer to the predicted values. During the 2000 to 2004 period, the presence of the Joneses variables will in general reduce the estimated level of “excessive” holding. Indeed, the Joneses effect reverses the inference from "excessive” holding to "deficient" holding in the case of India, Philippines, and Thailand.

In sum the results from both the panel and economy-by-economy regressions are, in general, supportive of the notion that an economy's international reserve demand behavior is affected by other economies' action. ${ }^{16}$

Figure 1: Estimated Residuals from Models With and Without the Joneses Effect

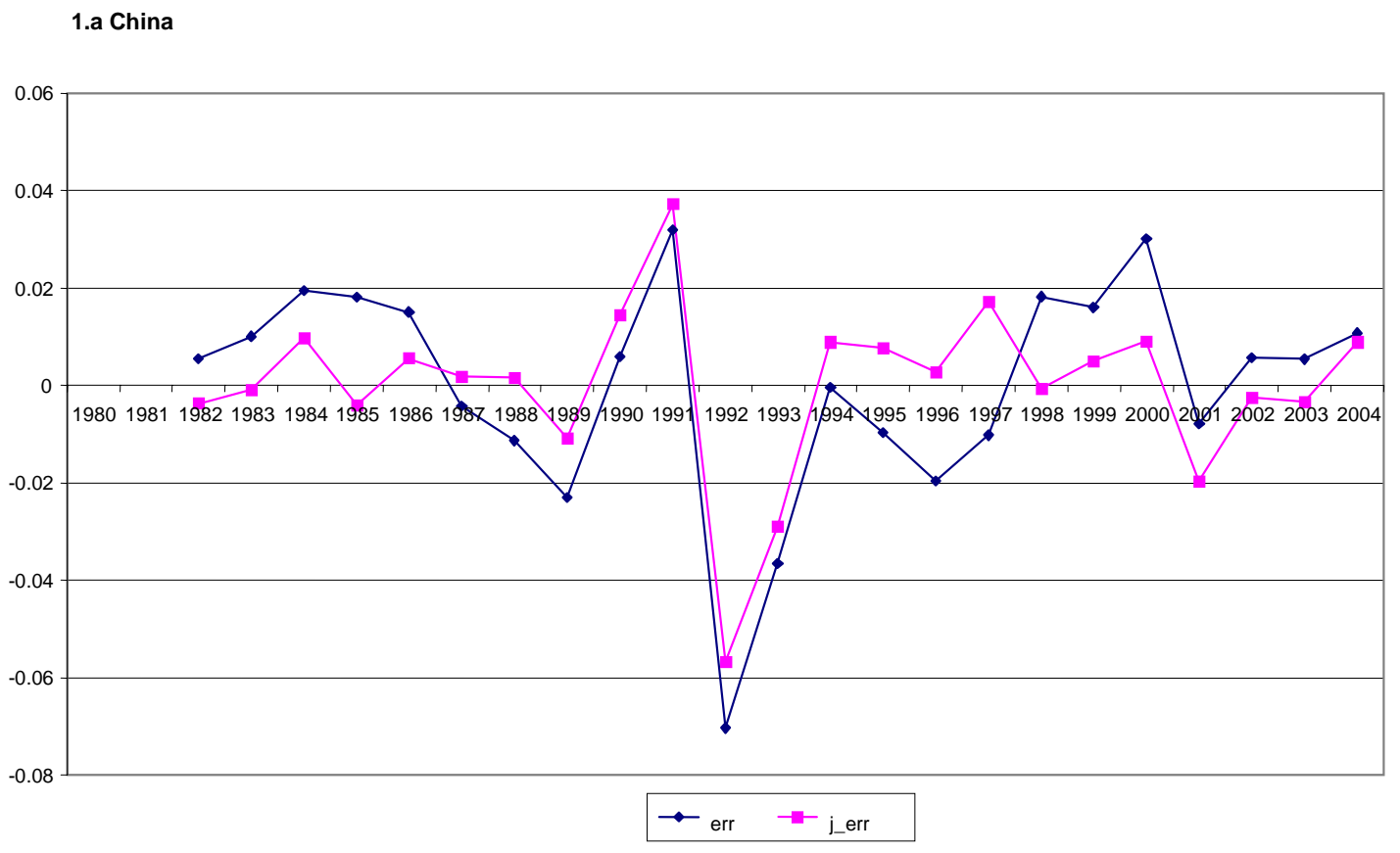

16 As a robust check, we added the lagged dependent variable as one of the regressors. The results, provided in the Appendix, on the Joneses results are qualitatively the same as those reported in the text. 


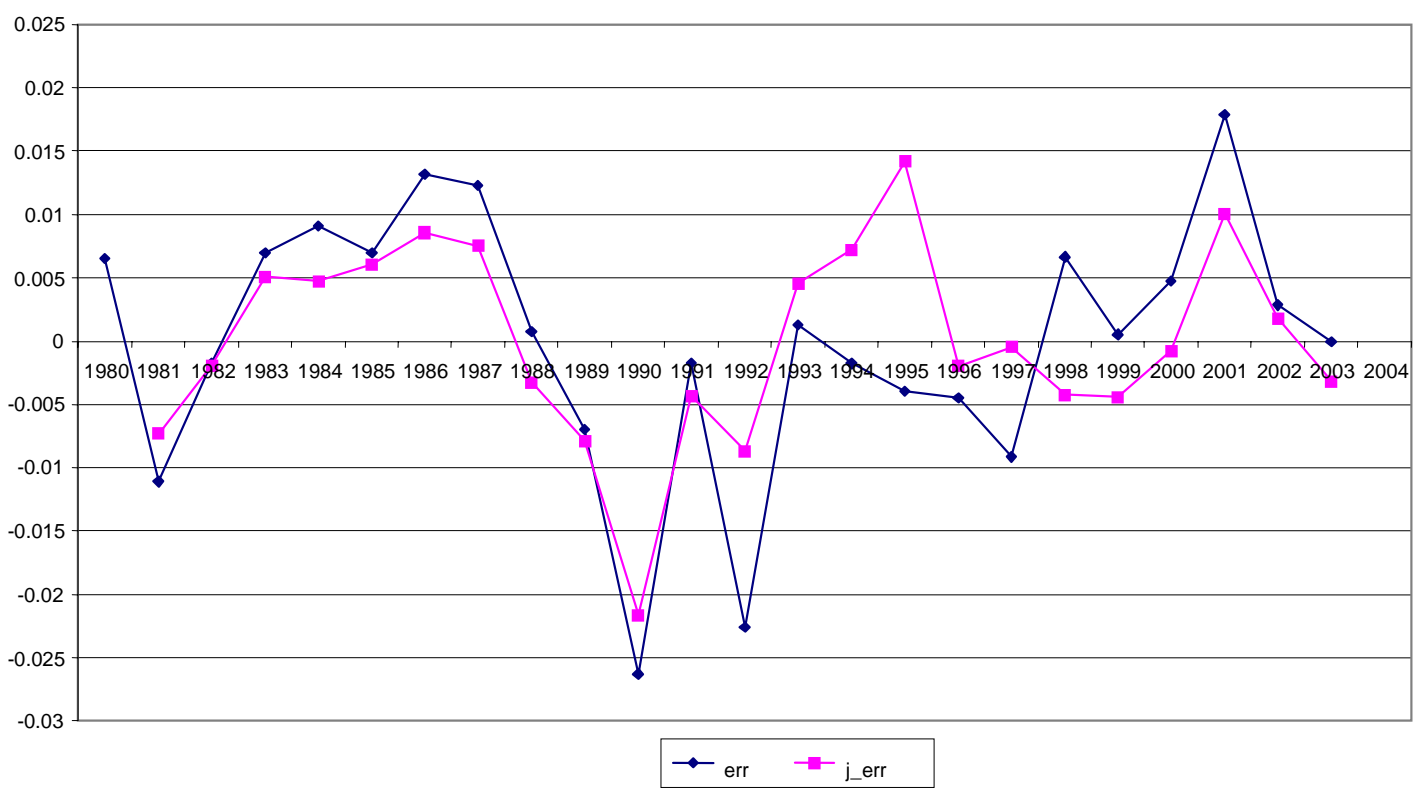

1.c Indonesia

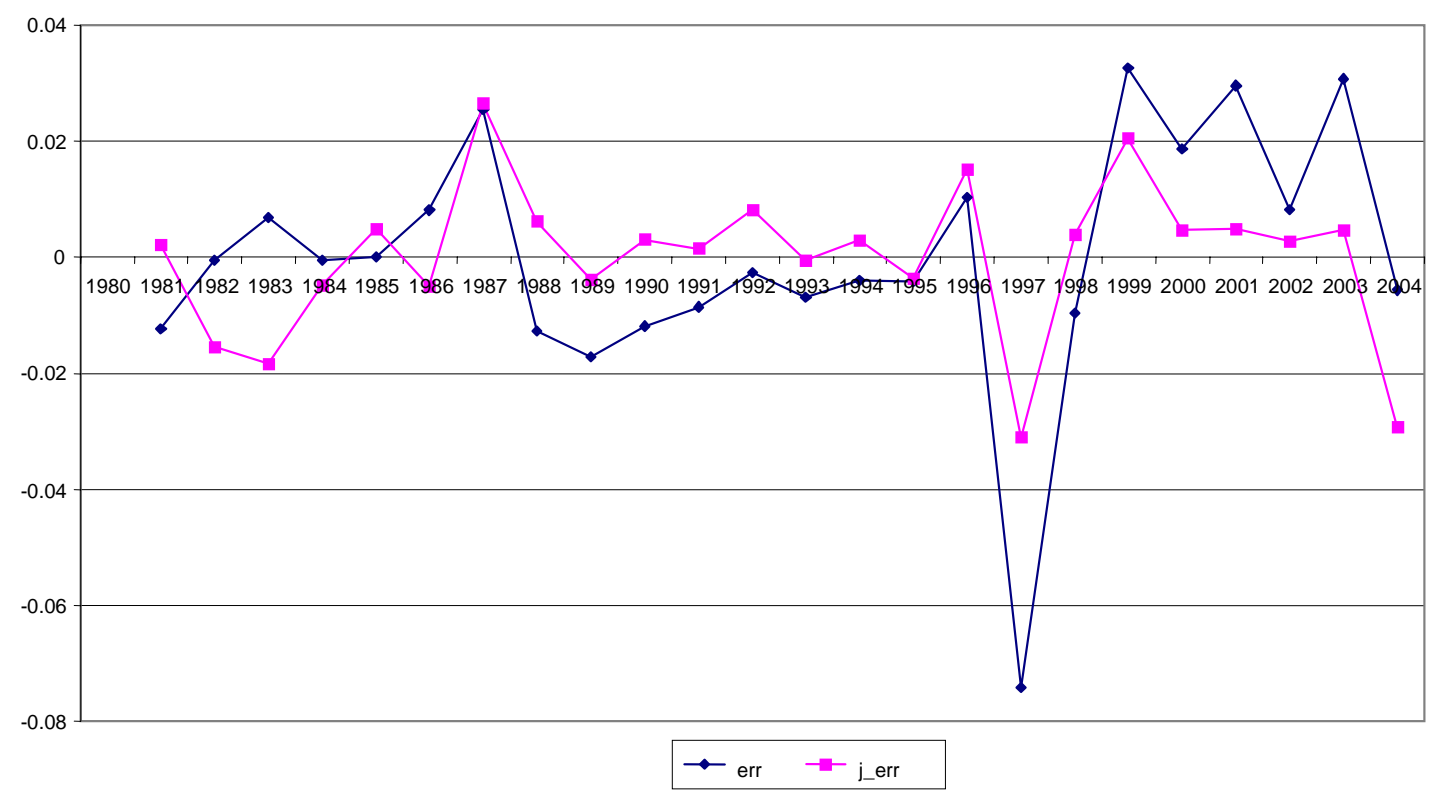


1.d Japan

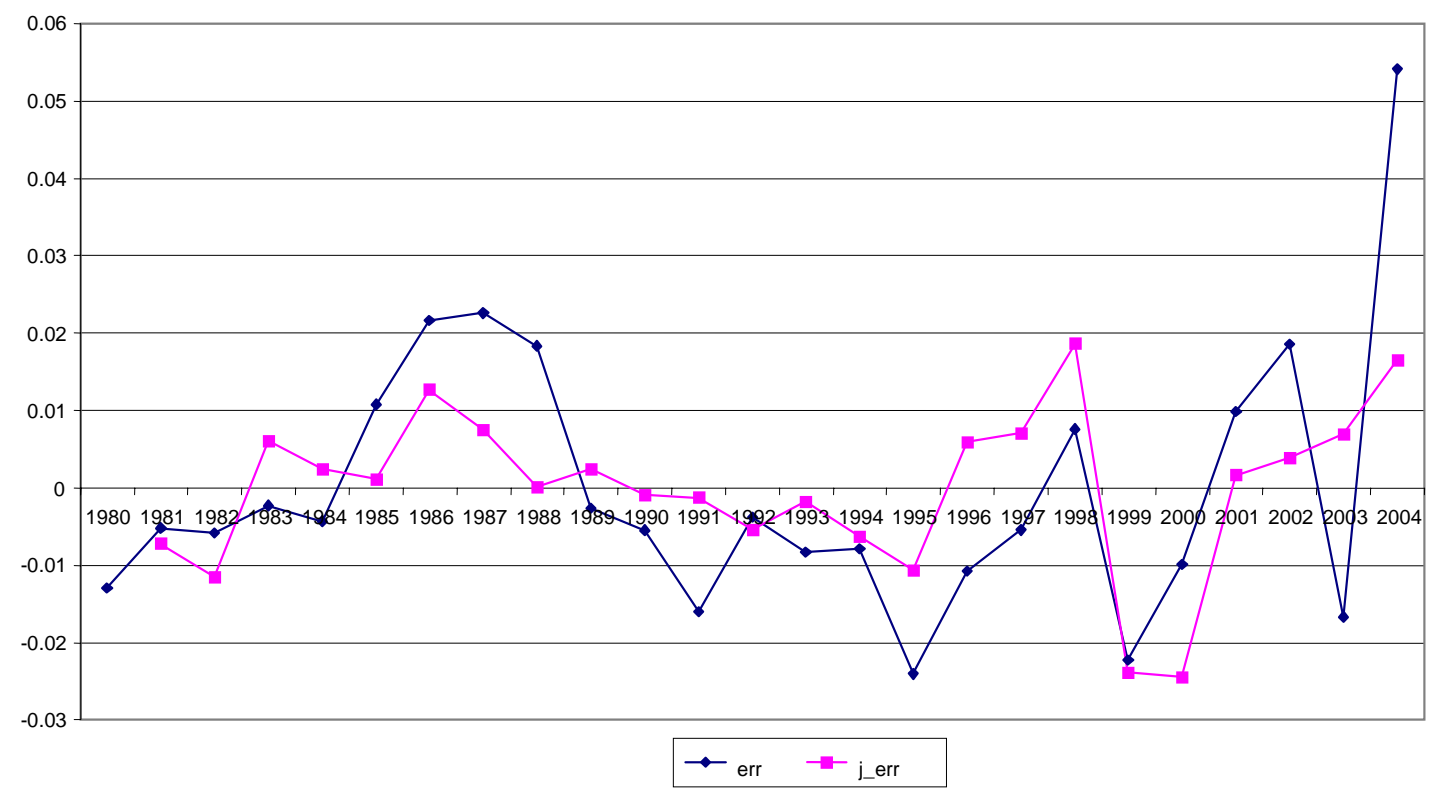

1.e Korea

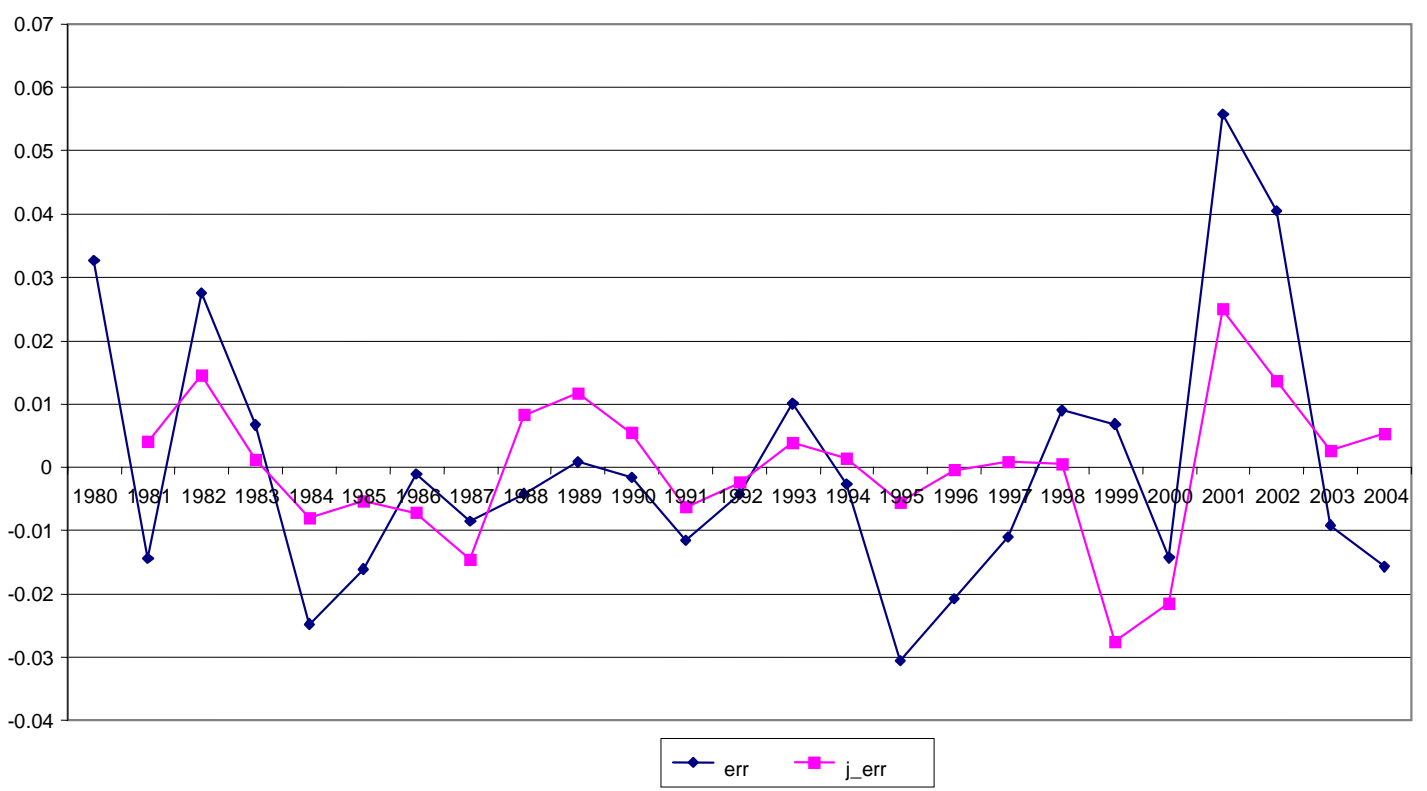


1.f Malaysia

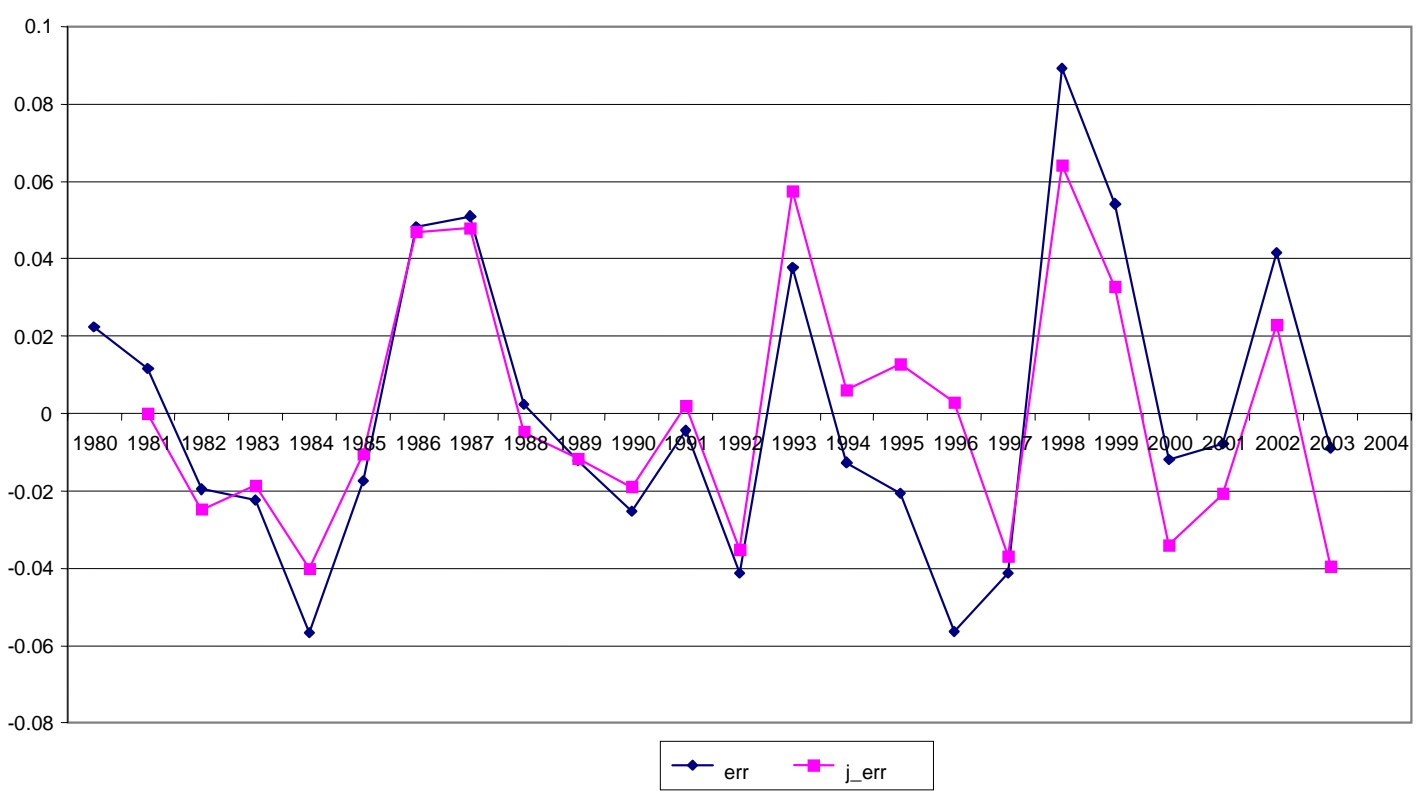

1.g Philippines

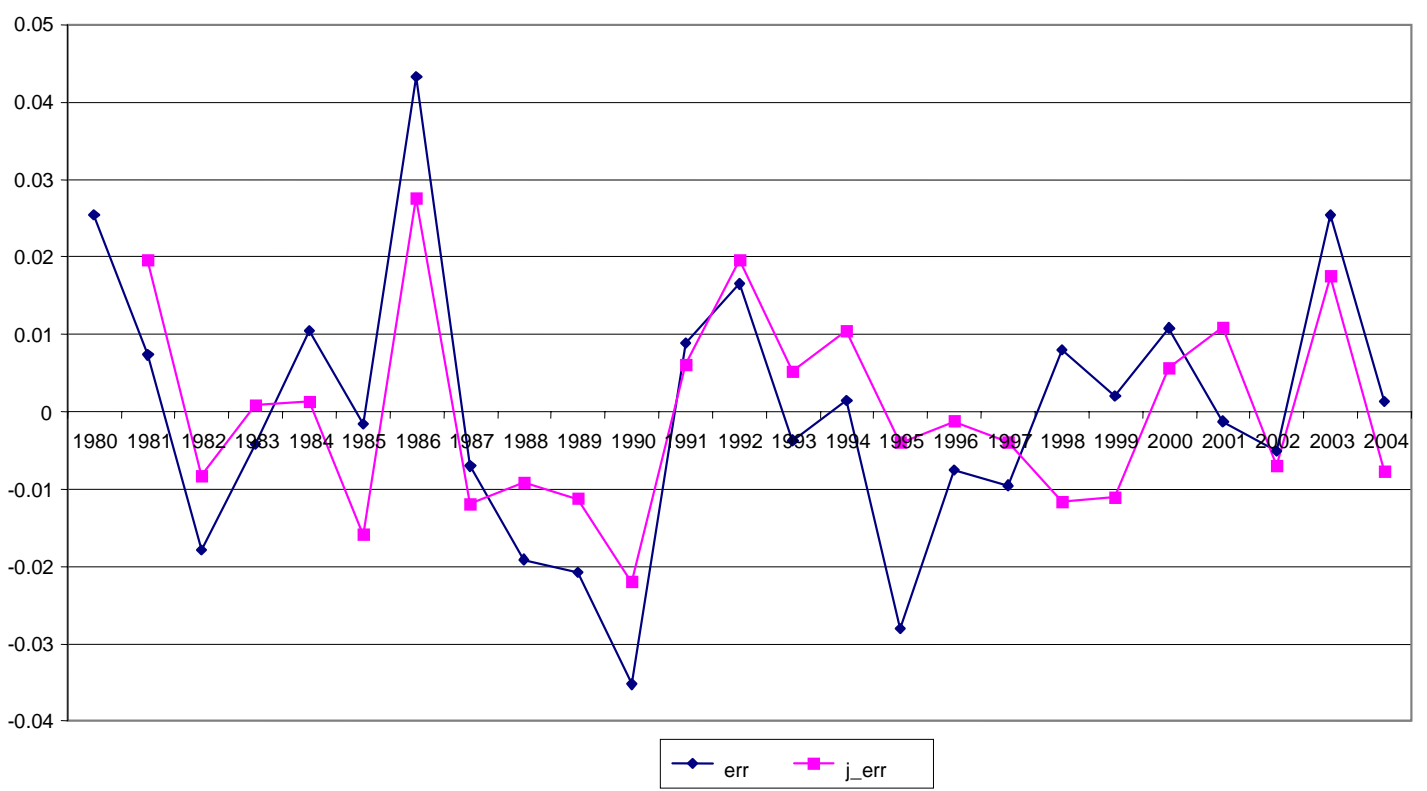




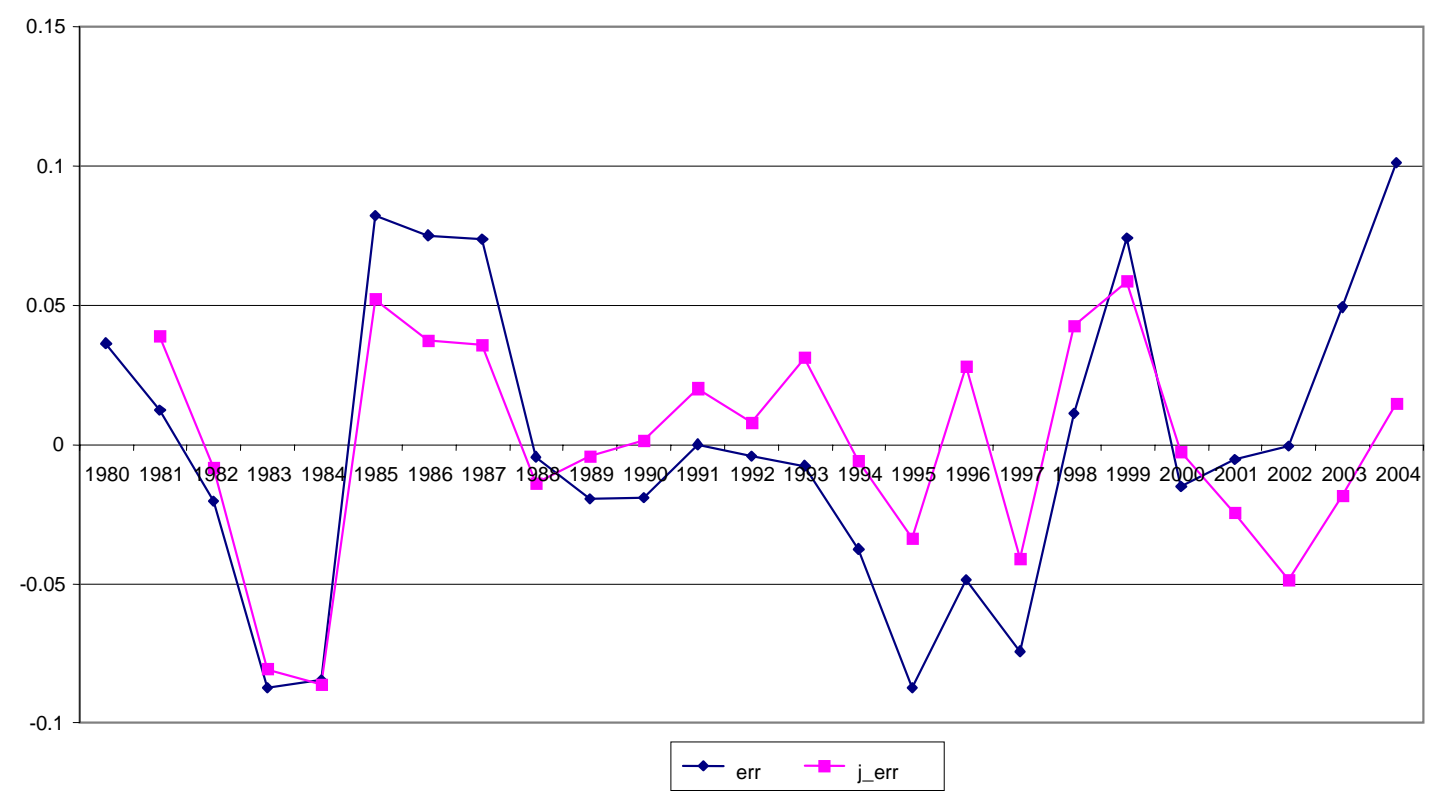

1.i Taiwan

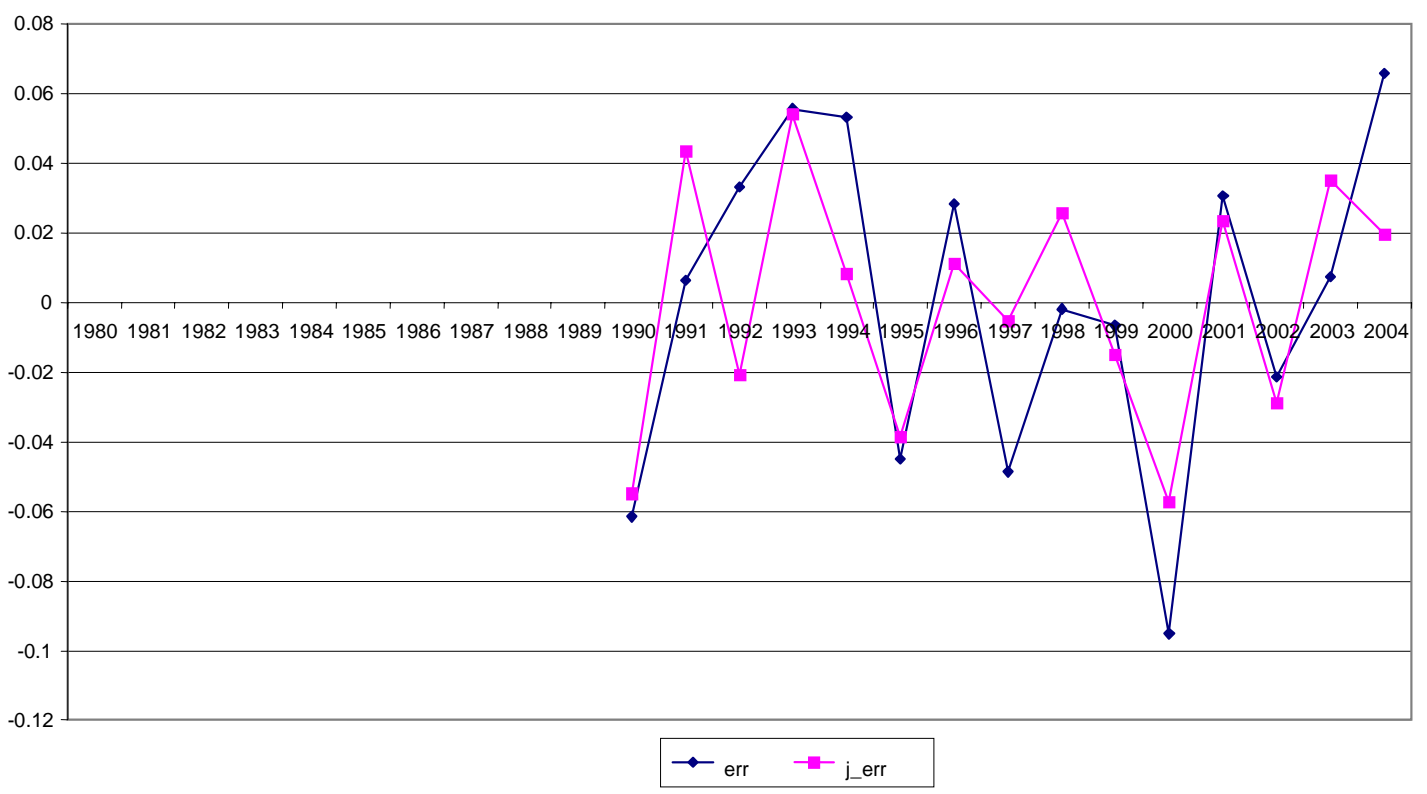




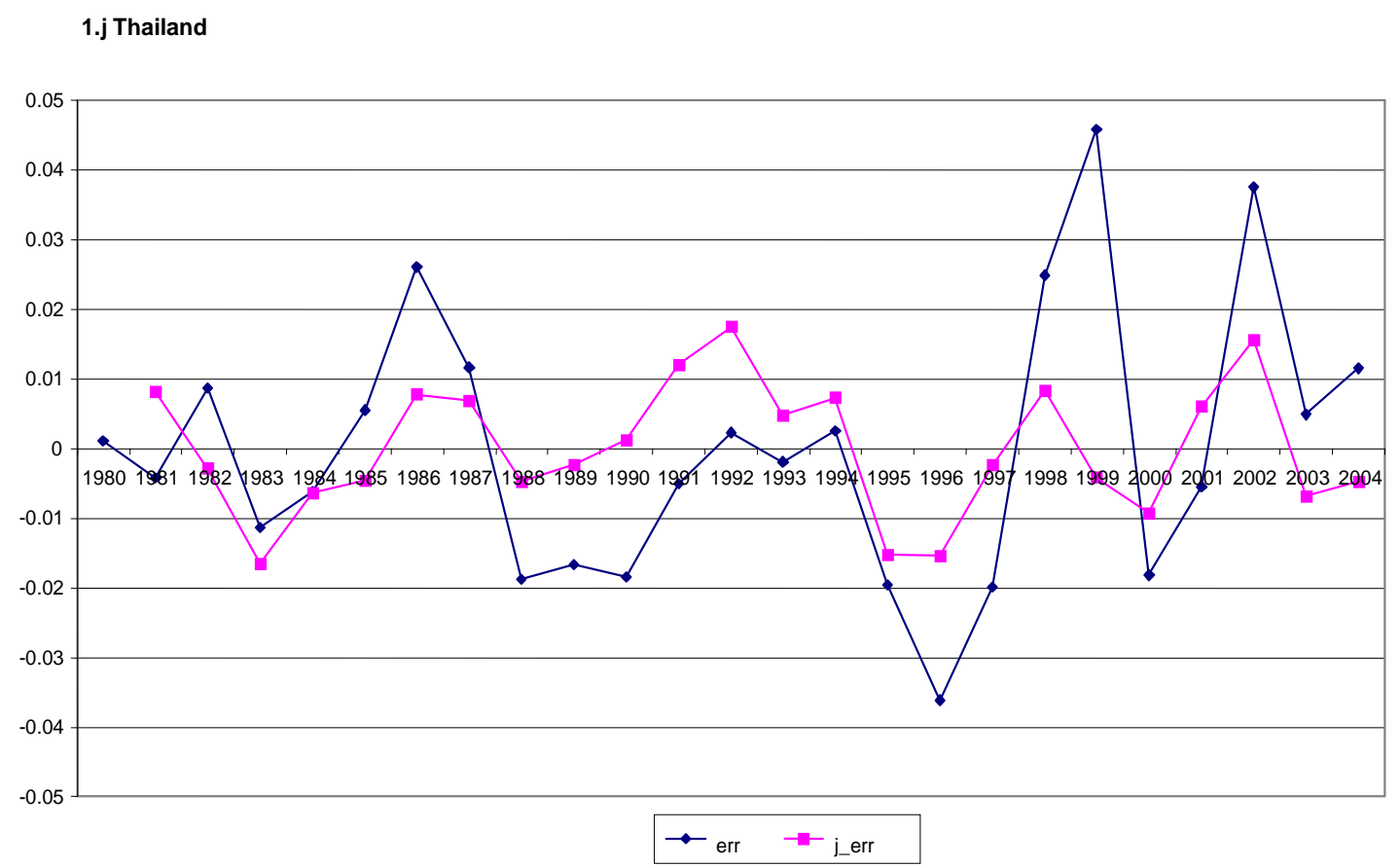

Notes: The line graph labeled "err" gives the estimated residuals from fitting individual economy data to the equation (20) in the text. Equation (20) includes only traditional macroeconomic variables as regressors. The line graph labeled “j_err” gives the estimated residuals from fitting individual economy data to the equation (22), which includes both the Joneses and the interactive Joneses variables.

\subsection{Additional Analyses}

A few additional analyses are conducted to evaluate the robustness of the empirical Joneses effect. First, we consider the Joneses variable defined by the five economies directly inflicted by the East Asian crisis; that is

$$
J_{i t}=\Sigma_{k=\text { Thailand, Malaysia, Philippines, Indonesia and Korea }} Y_{k t} \text {. }
$$

It may be argued that China, Japan and Taiwan are quite different from other economies in the sample. Economies in the region, instead, may use the five crisis-inflicted economies to formulate their international reserve hoarding strategies. To accommodate this possibility, we present the panel estimation results based on the Joneses variable defined by (25) in Table 5. Again, for any one of these five economies, the Joneses variable is defined to be the sum of the international reserves held by the other four economies.

One noticeable difference between results in Table 5 and those in Tables 1 and 2 is that the Joneses effect defined by the crisis- 5 economies is only statistically significant in the post- 
1997 period while the other two specifications of the Joneses variable are significant in both the pre- and post-1997 periods. That is, the evidence suggests that the recent East Asian financial crisis has put the international reserves of these five economies in spotlight. One possible interpretation is that other economies do not want to repeat the experiences of these crisisinflicted economies and, thus, pay attention to their levels of international reserves.

Table 5: Demand for international reserves with the Joneses variable defined by crisis-5 economies

\begin{tabular}{ccc}
\hline & Model (21) & Model (22) \\
\hline lngdppc & $0.0648^{* * *}$ & $0.0870^{* * *}$ \\
mp & $(3.26)$ & $(4.40)$ \\
& 0.0185 & 0.0228 \\
F_open & $(0.44)$ & $(0.57)$ \\
& $0.1377^{* *}$ & $0.1427^{* * *}$ \\
E_vol & $(3.27)$ & $(3.53)$ \\
& $0.0000^{* *}$ & 0.0000 \\
R_vol & $(2.11)$ & $(1.48)$ \\
& $0.0014^{* *}$ & $0.0012^{*}$ \\
Joneses_5 & $(2.19)$ & $(1.83)$ \\
& $0.1288^{* * *}$ & 0.0152 \\
I $>97^{*}$ Joneses_5 & $(5.79)$ & $(0.45)$ \\
& & $0.0719^{* * *}$ \\
constant & & $(4.34)$ \\
Adj. R-squares & $-0.4139 * * *$ & $-0.5413^{* * *}$ \\
Observations & $(-2.82)$ & $(-3.76)$ \\
\end{tabular}

Note: The table reports the panel regression results of models (21) and (22) in the text. "Ingdppc" is log per capita GDP, "mp" is propensity to import, "F_open" is financial openness, "E_vol" is exchange volatility, and "R_vol" is international reserve volatility. "Joneses_5" is the Joneses variable defined by the crisis-5 economies; namely Indonesia, Korea, Malaysia, Philippines, and Thailand as stated in equation (25) in the text. "I>97*Joneses_5" is the interactive Joneses variable $\mathrm{I}(\mathrm{t}-1>97) * J_{i, t-1} . \mathrm{t}$-statistics are in parentheses. “***”, “**”, and “*” denote significance at the $1 \%, 5 \%$ and $10 \%$ level, respectively.

A few additional observations on the crisis-5 Joneses variable results are in order. First, it is noted that the use of the crisis- 5 Joneses variable does not have a large impact on coefficient 
estimates of the standard economic factors in, say, Table 1. Second, the adjusted R-squares in Table 5 are comparable to the corresponding ones in Tables 1 and 2; indicating that models with the crisis-5 Joneses variable offer explanatory power similar to models with the other specifications of the Joneses variable. Third, the economy-by-economy regression results also suggest that the Joneses effect attributed to the crisis-5 economies mainly show up in the post1997 period. ${ }^{17}$ Specifically, under model (22) the interactive Joneses variable capturing the post1997 effect is statistically significant in eight of the ten cases and none of the Joneses variable is significant.

The empirical Joneses effect appears robust to the few ways we defined "the Joneses." One possible concern about the empirical Joneses variable is that it measures some common latent dynamics that drive the economies in the sample and, hence, their hoarding of international reserves. If it is the case, then the reported Joneses effect is spurious. To guide against this possibility, we re-examine the Joneses effect in the presence of a common output growth variable. It is perceived that output growth is a reasonable proxy for general economic conditions and, thus, a common output growth variable is a reasonable proxy for common latent factors that affect international reserve hoarding behavior.

Table 6 presents the Joneses effect in the presence of a common output growth variable, which is given by the principal component of GDP growth rates of the economies in the sample. It is quite encouraging to observe that the Joneses effect revealed in Table 6 is quite comparable to the one reported in, say, Table 1 . The common output growth variable has a significantly negative coefficient under model (21) and an insignificant one under (22). The coefficient estimates of other variables are similar to those in Table 1. According to the adjusted R-squares estimates, the inclusion of the common output growth variable marginally improves the models' goodness of fit. Even within the economy-by-economy regression framework, the significance of the Joneses variable is not materially affected by the inclusion of the common output growth variable. $^{18}$

17 These economy-by-economy results are reported in the Appendix.

18 Again, the results of estimating the economy-by-economy regression incorporating the common output growth variables are reported in the Appendix for brevity. 
Table 6: Demand for international reserves with both the Joneses variable and the common growth element

\begin{tabular}{ccc}
\hline & Model (21) & Model (22) \\
\hline Ingdppc & $0.0461^{* *}$ & $0.0691^{* * *}$ \\
& $(2.27)$ & $(3.35)$ \\
F_open & -0.0049 & -0.0163 \\
& $(-0.12)$ & $(-0.40)$ \\
E_vol & $0.1619^{* * *}$ & $0.1567^{* * *}$ \\
& $(4.01)$ & $(4.00)$ \\
R_vol & 0.0000 & 0.0000 \\
& $(1.53)$ & $(1.47)$ \\
Joneses & $0.0013^{* *}$ & 0.0010 \\
& $(2.10)$ & $(1.59)$ \\
I>97*Joneses & $0.0774 * * *$ & $0.0287 *$ \\
& $(6.73)$ & $(1.68)$ \\
PC_gdp_growth & & $0.0246 * * *$ \\
Constant & & $(3.76)$ \\
Adj. R-squares & $(-2.28)$ & 0.0041 \\
Observations & $-0.3229^{* *}$ & $(0.11)$ \\
& $(-2.22)$ & $-0.4261^{* * *}$ \\
\hline
\end{tabular}

Note: The table reports the panel regression results of models (21) and (22) in the text. "Ingdppc" is log per capita GDP, "mp" is propensity to import, "F_open" is financial openness, "E_Vol" is exchange volatility, and " $\mathrm{R} \_v o l$ " is international reserve volatility. "Joneses" is the Joneses variable defined by equation (23) in the text.

"I>97*Joneses" is the interactive Joneses variable I(t-1>97)* $J_{i, t-1}$. "PC_gdp_growth" is the principal component of the sample economies' GDP growth rates. t-statistics are in parentheses. “***”, “**”, and “*” denote significance at the $1 \%, 5 \%$ and $10 \%$ level, respectively.

Apparently, the information contents of the Joneses variable and the common output growth variable about international reserves do not overlap that much. The empirical Joneses effect is not induced by common latent dynamics represented by common output growth.

The estimation results based on an alternative specification of the possible latent factor are presented in Tables $7 \mathrm{a}$ and $7 \mathrm{~b}$. Since the common aggregate output indicator does not alter the empirical Joneses result, we use the lagged international reserve variable as a proxy for the 
Table 7.a: Results from individual economy with both the Joneses variable and the lagged dependent variable

\begin{tabular}{|c|c|c|c|c|c|c|c|c|c|c|}
\hline & China & India & Indonesia & Japan & Korea & Malaysia & Philippines & Singapore & Taiwan & Thailand \\
\hline \multirow[t]{2}{*}{ L_rg_ratio } & $0.4891^{*}$ & $0.7109 * * *$ & $0.4173^{* * *}$ & $1.0884 * * *$ & $0.6869 * * *$ & 0.0385 & 0.3159 & 0.3827 & $0.8139 * *$ & $0.4474 * *$ \\
\hline & $(2.02)$ & $(4.30)$ & (3.94) & (11.07) & $(4.16)$ & $(0.16)$ & $(1.51)$ & (1.61) & $(3.26)$ & $(2.58)$ \\
\hline \multirow[t]{2}{*}{ lngdppc } & 0.0711 & 0.0564 & -0.0183 & -0.0057 & 0.0454 & -0.0082 & -0.1034 & -0.0833 & -0.1542 & 0.0322 \\
\hline & $(1.54)$ & $(1.26)$ & $(-0.66)$ & $(-0.40)$ & $(1.16)$ & $(-0.05)$ & $(-1.18)$ & $(-0.72)$ & $(-0.86)$ & $(0.77)$ \\
\hline \multirow[t]{2}{*}{$\mathrm{mp}$} & -0.1987 & -0.0727 & 0.1852 & 0.0031 & 0.0933 & 0.1107 & $0.3206^{* *}$ & $-0.2684 * * *$ & 0.1296 & 0.0785 \\
\hline & $(-0.58)$ & $(-0.20)$ & $(0.97)$ & $(0.03)$ & $(0.35)$ & $(0.59)$ & $(2.58)$ & $(-2.95)$ & $(0.23)$ & $(0.75)$ \\
\hline \multirow[t]{2}{*}{ F_open } & -0.2204 & -0.1320 & -0.0145 & -0.0339 & -0.0858 & -0.0099 & $0.0995 * *$ & -0.0725 & 0.0408 & $0.4407^{* * *}$ \\
\hline & $(-0.61)$ & $(-0.57)$ & $(-0.04)$ & $(-1.14)$ & $(-0.48)$ & $(-0.05)$ & $(2.24)$ & $(-1.42)$ & $(0.12)$ & $(4.02)$ \\
\hline \multirow[t]{2}{*}{ E_Vol } & -0.0404 & -0.0022 & $0.0001^{* * *}$ & -0.0000 & $-0.0002 * *$ & -0.1774 & -0.0069 & 0.1350 & 0.0247 & -0.0042 \\
\hline & $(-0.55)$ & $(-0.83)$ & $(3.50)$ & $(-0.11)$ & $(-2.13)$ & $(-1.64)$ & $(-1.64)$ & $(0.23)$ & $(1.05)$ & $(-1.46)$ \\
\hline \multirow[t]{2}{*}{ R_Vol } & $0.0029 * *$ & $0.0069 * * *$ & 0.0023 & $0.0005^{* * *}$ & $0.0112 * * *$ & $0.0396 * * *$ & 0.0017 & $0.0346 * *$ & $0.0105 * *$ & $-0.0094^{*}$ \\
\hline & $(2.46)$ & $(4.10)$ & $(0.20)$ & $(4.24)$ & $(5.84)$ & $(3.22)$ & $(0.09)$ & $(2.58)$ & $(2.40)$ & $(-1.87)$ \\
\hline \multirow[t]{2}{*}{ Joneses } & -0.0126 & -0.0093 & 0.0180 & 0.0018 & -0.0280 & 0.0620 & 0.0013 & $0.1072 * *$ & 0.0707 & $0.0452 * *$ \\
\hline & $(-0.38)$ & $(-0.78)$ & $(1.40)$ & $(0.26)$ & $(-1.34)$ & (1.39) & $(0.09)$ & $(2.28)$ & $(0.98)$ & $(2.74)$ \\
\hline \multirow[t]{2}{*}{ constant } & -0.3342 & -0.2916 & 0.0882 & 0.0548 & -0.3604 & 0.0948 & 0.6526 & 1.5321 & 1.2821 & -0.2814 \\
\hline & $(-1.50)$ & $(-1.37)$ & $(0.58)$ & $(0.38)$ & $(-0.97)$ & $(0.08)$ & $(1.10)$ & (1.39) & $(0.81)$ & $(-1.02)$ \\
\hline Adj R-Squares & 0.9248 & 0.9590 & 0.9288 & 0.9901 & 0.9625 & 0.7970 & 0.9031 & 0.9104 & 0.9254 & 0.9709 \\
\hline Observations & 23 & 23 & 24 & 24 & 24 & 23 & 24 & 24 & 15 & 24 \\
\hline
\end{tabular}

Note: The table reports the results of estimating model (21) economy by economy. "I_rg_ratio" is the lagged dependent variable, "Ingdppc" is $\log$ per capita GDP, “mp” is propensity to import, "F_open” is financial openness, "E-Vol” is exchange volatility, and " $\mathrm{R} \_$vol” is international reserve volatility. "Joneses” is the Joneses variable defined by equation (23) in the text. t-statistics are in parentheses. “***”, “**”, and “*”” denote significance at the $1 \%, 5 \%$ and $10 \%$ level, respectively. 
Table 7.b: Results from individual economy with the period-specific Joneses variables and the lagged dependent variable

\begin{tabular}{|c|c|c|c|c|c|c|c|c|c|c|}
\hline & China & India & Indonesia & Japan & Korea & Malaysia & Philippines & Singapore & Taiwan & Thailand \\
\hline \multirow[t]{2}{*}{ l_rg_ratio } & 0.0552 & $0.5242 * * *$ & $0.2660 *$ & $1.0889 * * *$ & $0.3783 * *$ & 0.1224 & 0.2744 & $0.6317 * *$ & 1.0430 & 0.0640 \\
\hline & $(0.18)$ & $(2.95)$ & $(2.02)$ & $(10.51)$ & $(2.62)$ & $(0.52)$ & $(1.70)$ & $(2.41)$ & (1.80) & (0.39) \\
\hline \multirow[t]{2}{*}{ lngdppc } & $0.0863 *$ & 0.0171 & 0.0184 & -0.0057 & 0.0183 & -0.0703 & $-0.1555^{* *}$ & -0.1092 & 0.0888 & $0.1553 * * *$ \\
\hline & $(2.01)$ & $(0.38)$ & $(0.55)$ & $(-0.38)$ & $(0.62)$ & $(-0.45)$ & $(-2.24)$ & $(-1.00)$ & $(0.15)$ & (3.43) \\
\hline \multirow[t]{2}{*}{$\mathrm{mp}$} & -0.2307 & 0.0672 & 0.1979 & 0.0038 & -0.0253 & 0.1536 & $0.2490 * *$ & $-0.2211^{* *}$ & -0.1938 & 0.0340 \\
\hline & $(-0.73)$ & (0.19) & (1.10) & $(0.04)$ & $(-0.13)$ & $(0.86)$ & $(2.54)$ & $(-2.48)$ & $(-0.20)$ & $(0.43)$ \\
\hline \multirow[t]{2}{*}{ K_open } & -0.0920 & 0.1836 & 0.0360 & -0.0338 & 0.0061 & -0.1194 & 0.0490 & -0.0767 & -0.0067 & $0.3025^{* * *}$ \\
\hline & $(-0.27)$ & $(0.69)$ & $(0.10)$ & $(-1.09)$ & $(0.05)$ & $(-0.57)$ & $(1.32)$ & $(-1.60)$ & $(-0.02)$ & (3.38) \\
\hline \multirow[t]{2}{*}{ E_Vol } & -0.0374 & -0.0013 & $0.0000 * *$ & -0.0000 & $-0.0001 *$ & -0.1434 & $-0.0057 *$ & 0.1480 & -0.0100 & $-0.0083^{* * *}$ \\
\hline & $(-0.56)$ & $(-0.52)$ & $(2.76)$ & $(-0.10)$ & $(-1.98)$ & $(-1.38)$ & $(-1.74)$ & $(0.27)$ & $(-0.12)$ & $(-3.44)$ \\
\hline \multirow[t]{2}{*}{ R_Vol } & $0.0038 * * *$ & $0.0073 * * *$ & -0.0049 & $0.0005^{* * *}$ & $0.0062 * * *$ & $0.0460 * * *$ & 0.0286 & $0.0427 * * *$ & $0.0100 *$ & -0.0010 \\
\hline & (3.26) & $(4.71)$ & $(-0.41)$ & $(4.08)$ & (3.32) & (3.80) & $(1.72)$ & (3.20) & $(2.12)$ & $(-0.23)$ \\
\hline \multirow[t]{2}{*}{ Joneses } & -0.0331 & -0.0062 & -0.0059 & 0.0019 & -0.0065 & 0.0162 & -0.0150 & -0.0066 & -0.0758 & -0.0041 \\
\hline & $(-1.03)$ & $(-0.57)$ & $(-0.32)$ & $(0.25)$ & $(-0.40)$ & $(0.33)$ & $(-1.25)$ & $(-0.09)$ & $(-0.22)$ & $(-0.23)$ \\
\hline \multirow[t]{2}{*}{ I $>97 *$ Joneses } & $0.0200 *$ & $0.0073 *$ & $0.0159 *$ & -0.0000 & $0.0282 * * *$ & $0.0259 *$ & $0.0214^{* * *}$ & $0.0434 *$ & 0.0478 & $0.0273^{* * *}$ \\
\hline & (1.99) & (1.99) & $(1.76)$ & $(-0.02)$ & (3.88) & $(1.74)$ & $(3.45)$ & $(1.80)$ & $(0.45)$ & (3.73) \\
\hline \multirow[t]{2}{*}{ constant } & $-0.3712 *$ & -0.0868 & -0.0985 & 0.0543 & -0.1167 & 0.6035 & $1.0440 * *$ & 1.6277 & -0.6989 & $-1.0232 * * *$ \\
\hline & $(-1.82)$ & $(-0.39)$ & $(-0.56)$ & $(0.36)$ & $(-0.42)$ & $(0.55)$ & $(2.21)$ & (1.57) & $(-0.15)$ & $(-3.58)$ \\
\hline Adj R-Squares & 0.9372 & 0.9658 & 0.9371 & 0.9894 & 0.9801 & 0.8212 & 0.9423 & 0.9215 & 0.9157 & 0.9839 \\
\hline Observations & 23 & 23 & 24 & 24 & 24 & 23 & 24 & 24 & 15 & 24 \\
\hline
\end{tabular}

Note: The table reports the results of estimating model (22) economy by economy. "l_rg_ratio” is the lagged dependent variable, “lngdppc” is the log per capita GDP, “mp” is the import propensity, “F_open” is financial openness, “E_Vol” is exchange volatility, and “R_vol” is international reserve volatility. “Joneses” is the Joneses variable defined by equation (23) in the text. "I>97*Joneses” is the interactive Joneses variable I(t-1>97)* $J_{i, t-1}$. t-statistics are in parentheses. “***”, “**”, and “*” denote significance at the $1 \%$, 5\% and $10 \%$ level, respectively. 
possible latent factor. In contrast to common output growth, individual lagged international reserve variables are used in their respective economy-by-economy regression equations to capture the possibility of economy-specific latent factors.

The presence of lagged international reserves does not substantially alter the inference of the Joneses effect. Comparing with results in, say, Table 3b, there is a lower frequency of the Joneses effect in Table 7a. On other hand, the post-1997 Joneses effect in Table 7b is slightly more widespread than the one found in Table $3 c$ - there are eight significant Joneses variables in the former and seven in the latter. Indeed, the significantly negative Taiwanese Joneses effect in Table 3c becomes a positive, though not significant, effect in Table 7b. On the average, the evidence does not weaken the empirical Joneses effect.

\section{Concluding Remarks}

In this exercise, we explore a motive for hoarding international reserves that was advocated by Fritz Machlup in the 1960s. Specifically, we consider the Mrs Machlup’s wardrobe hypothesis and the related keeping up with the Joneses argument. Motivated by events that happened in the post-1997 crisis period, we speculate that, in addition to psychological reasons, there may be economic reasons underlying the keeping up with the Joneses behavior. For instance, if an economy is holding a level of international reserves that is relatively lower than the Joneses, it is more vulnerable to speculative attacks. Further, for developing economies, international reserves can have a positive impact on their growth prospects, which, in turn can reduce their vulnerability to crises. We use a stylized model to illustrate these effects on the hoarding of international reserves.

A canonical empirical international reserve demand equation is used to investigate the presence of the Joneses effect in a group of East Asian economies. Both linear and panel-based regression results are suggestive of the presence of the Joneses effect; especially in the post-1997 crisis period. Individual economy estimation results, however, show that the Joneses effect is not uniform across economies.

There are a few caveats. First, the stylized model is used to highlight the Joneses effect. It does not, however, imply that other motivations for holding international reserves are not important. For instance, the increasing capital mobility and growing financial account liberalization around the world will boost the demand for international reserves to smooth out 
payment imbalances. However, our exercise demonstrates that one seemingly non-economic reason, the so-called Mrs Machlup's wardrobe hypothesis, may help account for the part of international reserve accumulation that is not explained by standard macroeconomic variables. We realize that the Joneses effect varies across economies and does not necessarily affect all the economies around the world. However, there is a reason to believe that the Joneses effect is in play for some Asian economies.

Second, our empirical evidence is meant to be illustrative rather than definitive. For one thing, we do not have a priori information on "the Joneses" of a given economy. Our choice of economies is based on convenience and the recent discussions in the media. Further, there is a possibility that our Joneses variable is correlated with some latent variables that drive demand for international reserves. To contemplate these issues, we consider three different definitions of the Joneses variable and two alternative approaches to capture latent variables. The empirical evidence, in general, is indicative of the presence of the Joneses effect. Arguably, the study of Joneses effects will be benefited from a more elaborate framework of demand for international reserves.

In the text, it is asserted that, in addition to psychological reasons, the keeping up with the Joneses effect can have some economic content. Specifically, the probability of speculative attack and the effect on output are deemed relevant factors for the peer group effect. While the two arguments appear reasonable, we provide no empirical evidence to substantiate the claim. The paucity of data is the main excuse. For instance, sovereign spreads (or ratings) may be used as a proxy for the probability of having a speculative attack. Nonetheless, we do not have these data for the sample under considerations. ${ }^{19}$ On the output effect, the results are mostly theoretical ones based on the perception that international reserves mitigate the output loss/adjustment cost during the crisis time and prevent financial crises, hence, improve the output outlook. ${ }^{20}$

At the risk of repeating, we have to point out again that the empirical Joneses effect may be due to any mechanisms that give rise to competitive hoarding behavior including the implicit psychological motivation mentioned in Machlup (1966). Instead of viewing the empirical results

19 Recently, Garcia and Soto (2004) find that the ratio of international reserves to short-term debts explains the occurrence of crises. Noted that their proxy for crisis is given by a weighted average of the first differences in real exchange rate and the level of international reserves. 20 See, for example, Aizenman, et al. (forthcoming), Aizenman and Lee (2005), and BenBassat and Gottieb (1992). 
as definite evidence of the Joneses effect, we can say that, for some economies, there is evidence of inter-dependence of their holdings of international reserves and the evidence is robust to the presence of standard macro determinants, a few controls, and a few alternative specifications of the "Joneses” variable. Unfortunately, without a formal model to separate the potential causes of competitive behavior, it is hard to empirically disentangle them. Further analyses of these arguments, which are beyond the scope of the current study, will shed additional insights into the Joneses effect. 


\section{References}

Abel, Andrew B., 1990, “Asset Prices under Habit Formation and Catching up with the Joneses,” American Economic Review 80, 38-42.

Aizenman, Joshua and Jaewoo Lee, 2005, “International Reserves: Precautionary Versus Mercantilist Views, Theory and Evidence,” NBER Working Paper 11366.

Aizenman, Joshua, Yeonho Lee, and Yeongseop Rhee, forthcoming, "International Reserves Management and Capital Mobility in a Volatile World: Policy Considerations and a Case Study of Korea,” Journal of the Japanese and International Economies.

Aizenman, Joshua, and Nancy Marion, 2003, “The High Demand for International Reserves in the Far East: What's Going On?” Journal of the Japanese and International Economies $17,370-400$.

Baumol, William J., 1952, “The Transactions Demand for Cash: an Inventory Theoretic Approach,” Quarterly Journal of Economics 66, 545-56.

de Beaufort Wijnholds, J.Onno and Arend Kapteyn, 2001, “International Reserve Adequacy in Emerging Market Economies,” International Monetary Fund WP/01/43.

Ben-Bassat, Avraham and Daniel Gottlieb, 1992, “Optimal International Reserves and Sovereign Risk,” Journal of International Economics 33, 345-362.

Day, Phillip and Hae Won Choi, 2004, “Asian Central Banks Consider Alternative to Big Dollar Holdings,” Wall Street Journal, February 5, 2004.

Diamond, Douglas W. and Philip H. Dybvig, 1983, "Bank Runs, Liquidity and Deposit Insurance,” Journal of Political Economy 91, 401-419.

Dooley, Michael, David Folkerts-Landau and Peter Garber, 2005, “International Financial Stability: Asia, Interest Rates, and the Dollar,” Deutsche Bank Global Research.

Feldstein, Martin, 1999, “Self-protection for emerging market economies,” NBER Working Paper 6097.

Flood, Robert, and Nancy Marion, 2002, “Holding International Reserves in an Era of High Capital Mobility,” International Monetary Fund WP/02/62.

Fischer, Stanley, 1999, “On the Need for an International Lender of Last Resort,” Journal of Economic Perspectives 13, 85-104.

Frenkel, Jacob, 1974, “Openness and the demand for International Reserves,” in Robert Z. Albier (Ed.), National Monetary Policies and the International Financial System, University of Chicago Press, Chicago. 
Frenkel, Jacob, and Boyan Jovanovic, 1980, “On Transactions and Precautionary Demand for Money,” Quarterly Journal of Economics 90, 25-43.

Frenkel, Jacob, and Boyan Jovanovic, 1981, “Optimal International Reserves: A Stochastic Framework,” Economic Journal 91, 507-14.

Garcia. Pablo and Claudio Soto, 2004, “Large Hoarding of International Reserves: Are They Worth It?” manuscript, Chilean Central Bank Working paper No. 299.

Genberg, Hans, Robert McCauley, Yung Chul Park, and Avinash Persaud, 2005, “Official Reserves and Currency Management in Asia: Myth, Reality and the Future,” Geneva Reports on the World Economy 7, International Center for Monetary and Banking Studies.

Greenspan, Alan, 1999, “Currency Reserves and debt,” remarks made before the World Bank Conference on Recent Trends in International Reserves Management, Washington, D.C., April 29, 1999, http://www.federalreserve.gov/BoardDocs/Speeches/1999/19990429.htm. Grubel, Herbet G., 1971, “The Demand for International Reserves: A Critical Review of the Literature,” Journal of Economic Literature 9, 1148-1166.

Heller, Heinz R., 1966, “Optimal International Reserves,” Economic Journal 76, 296-311. Jeanne, Olivier and Romain Rancière, 2006, “The Optimal Level of International Reserves for Emerging Market Countries: Formulas and Applications,” International Monetary Fund WP/06/229.

Lane, Philips R. and Dominc Burke, 2001, “The Empirics of Foreign International Reserves,” Open Economies Review 12, 423-434.

Lee, Jaewoo, 2004, “Insurance Value of International Reserves: An Option Pricing Approach,” manuscript, Research Department, International Monetary Fund.

Machlup, Fritz, 1966, “The Need for Monetary International Reserves,” Reprints in International Finance 5. Princeton University.

Tobin, James, 1956, “The Interest Elasticity of Transactions Demand for Cash,” Review of Economics and Statistics 38, 241-70.

Xinhua News Agency, 2004, “China Sets No Target for Forex Reserve,” http://news.xinhuanet. com/english/2004-03/07/content_1350147.htm. 


\section{Appendix}

\section{A. $\quad$ The risk premium}

Because of the default risk, the home economy has to pay a risk premium to borrow in the global capital market. This leads the foreign debt interest rate that home country has to pay to be higher than the world interest rate. To illustrate the point, suppose the home economy defaults only in the bad state of nature. The expected debt service is

$$
E[S]=(1-p)(1+r) B+p \cdot[(1-q)(1+r) B+q \cdot \theta \cdot(1-\varepsilon)]
$$

With (5) in the text,

$$
\left(1+r^{*}\right) B=(1-p)(1+r) B+p \cdot[(1-q)(1+r) B+q \cdot \theta \cdot(1-\varepsilon)]
$$

Re-arranging, we obtain

$$
(1+r)(1-p q) B=\left(1+r^{*}\right) B-p q \theta(1-\varepsilon)
$$

Since the default occurs when $(1+r) B>\theta(1-\varepsilon)$, (A3) can be rewritten as

$$
(1+r)(1-p q) B>\left(1+r^{*}\right) B-p q(1+r) B,
$$

which can be simplified to $(1+r) B>\left(1+r^{*}\right) B$, and, thus, for a positive borrowing $B$

$$
r>r^{*} \text {. }
$$




\section{B. $\quad$ The Output effect of International Reserves}

The Aizenman and Lee (2005) model, which is based on the work of Diamond and Dybvig (1983), is used to illustrate the output effect of international reserves. In this setting, international reserves help cushion the output effect of liquidity shocks. Consider an economy that finances a long term project via bank loans. The representative agent is both the entrepreneur and the banker who does the financing and investment.

In period 1, the risk neutral central planner borrows $B$ in the global capital market and makes deposit in the bank. The deposit $B$ has two components - one component is international reserve holding, $R$ that does not go into the production process and the other component $(B-R)$ is used to finance the long term investment. The long term investment is undertaken prior to the realization of a liquidity shock. Note that it is the central planner who decides on the allocation of $B$ between international reserves $R$ and productive capital $(B-R)$. The reprehensive agent only does the financing and investment.

At the beginning of period 2, a stochastic liquidity (sudden stop) shock is realized with the aggregate value of $Z$. The shock, say, is affected by a speculative attack. If the realization $Z$ is less than the holding of international reserves, $R$, the economy uses the international reserve holding $R$ to fill in the sudden drop in liquidity and produces with capital $(B-R)$. Thus, the economy does not suffer from output losses.

On the other hand, if $Z$ is greater than $R$, then it triggers a premature liquidation of amount $(Z-R)$. The liquidation is accompanied by an adjustment cost that is proportional to $(Z-R)$, say $\lambda(Z-R), 0<\lambda<1$. Therefore, when the level of international reserves is not large enough to cover the amount of sudden drop in liquidity, the economy suffers an output loss. The net capital for the production in period 2 is,

$$
K_{2}=\left\{\begin{array}{ll}
(B-R)-(1+\lambda)(Z-R) & \text { if } Z>R \\
B-R & \text { if } Z \leq R
\end{array} .\right.
$$

The production technology of the long-term project in period 2 is given by

$$
Y_{2}=\left\{\begin{array}{ll}
A[(B-R)-(1+\lambda)(Z-R)] & \text { with probability } p \\
A[B-R] & \text { with probability } 1-p
\end{array},\right.
$$


where $A$ is the productivity parameter. ${ }^{21} A>1+r$, allows the economy at least to pay off the debt that carries an interest rate $r$. The probability of having a speculative attack that leads to output losses is $p$ and, in this case, $p=\operatorname{prob}(Z>R)$.

We express the liquidity shock in term of $B$ using $Z=z B$ and assume $z$ follows a uniform distribution in $[0,1]$. The expected output in period 2 is

$$
E\left(Y_{2}\right)=p A[(B-R)-(1+\lambda)(Z-R)]+(1-p) A[B-R] .
$$

Following the argument in Section 2.1, the deposit ceiling $\bar{B}$ is given by

$$
\left(1+r^{*}\right) \bar{B}=\theta \cdot p A[(\bar{B}-R)-(1+\lambda)(Z-R)]+\theta \cdot(1-p) A[\bar{B}-R]
$$

and $E\left(Y_{2}\right)$ is

$$
E\left(Y_{2}\right)=\left(1+r^{*}\right) \bar{B} / \theta \text {. }
$$

To proceed, we assume the risk premium, $r-r^{*}$, is given by

$$
r-r^{*}=\psi-\kappa \cdot \frac{R}{\widetilde{R}_{0}},
$$

where $\psi$ and $\kappa$ are the appropriate parameters, and $\widetilde{R}_{0}$ is the average of international reserves held by the Joneses. In essence, we assume the additional amount of interest the economy has to pay in the international capital market is negatively (positively) related to its own (peers') level of international reserves. Suppose there are two economies seeking loans in the international capital market. If the two economies are identical with exception that they hold different levels of international reserves. If lenders use international reserves as a measure of an economy's financial well being, then they are willing to offer the loan at a lower rate to the economy with a relatively higher level of international reserves. The parameter $\psi$ captures all the other factors determining the interest rate differential.

At the credit ceiling, it can be shown that the contractual repayment equals the default penalty in the best state of nature; that is $\bar{B}(1+r)=\theta \cdot A(\bar{B}-R)$. Substituting in (B6), we have

$$
\bar{B}=(\theta \cdot \lambda \cdot R) /\left(1+r^{*}+\psi-\kappa \cdot R / \tilde{R}_{0}\right) .
$$

From (B5) and (B7), we have

$$
E\left(Y_{2}\right)=\lambda \cdot\left(1+r^{*}\right) R /\left(1+r^{*}+\psi-\kappa \cdot R / \tilde{R}_{0}\right) .
$$

21 (B2) is a A-K model Cobb-Douglas function $Y=A K^{\alpha}$ with $\alpha=1$. 
Thus, (B8) shows that the expected output is positively associated with the economy's own level of international reserves and is negatively associated with its peer group's level. Further it can be shown that the effects of $R$ and $\tilde{R}_{0}$ on output levels when $Z>R$ or $Z \leq R$ are the same as their effect on the expected output. That is, own (peers') international reserves have a positive (negative) impact on output in both the crisis and non-crisis periods. As stated in the text, the specification (17) for output shocks is used to facilitate comparison with models in Sections 2.1 and 2.2. 


\section{Alternative presentation of the optimal levels of International Reserves}

Let $\eta=-\frac{d \log p}{d \log R}=-\frac{R}{p} \frac{d p}{d R}$ be the elasticity coefficient that measure the proportional change in speculative attack probability in response to a proportional change in the level of international reserves. With $\omega=\eta p$, we can rewrite $R_{b}$ as

$$
R_{b}=\omega(\delta+\varepsilon)\left[\frac{1}{\rho-r^{*}}+\frac{\theta}{1+r^{*}}\right] .
$$

Similarly, we can rewrite $R_{J}$ and $R_{J, F}$ as

$$
R_{J}=\omega_{J}(\delta+\varepsilon)\left[\frac{1}{\rho-r^{*}}+\frac{\theta}{1+r^{*}}\right],
$$

and

$$
R_{J, F}=\frac{\omega_{J}\left(\delta^{*}+\varepsilon^{*}\right) \tilde{R}_{0}\left[\frac{1}{\rho-r^{*}}+\frac{\theta}{1+r^{*}}\right]}{\tilde{R}_{0}-\left[\frac{1}{\rho-r^{*}}+\frac{\theta}{1+r^{*}}\right]},
$$

where $\omega_{J}$ is $\omega$ with $P$ replaced by $P_{J}$. These representations are simpler than those given in the text but they contain endogenous variables and, thus, strictly speaking, are not the solutions to the model. Note that $\omega_{J}>\omega$ and $\tilde{R}_{0} /\left\{\tilde{R}_{0}-\left[\left(1 / \rho-r^{*}\right)+\left(\theta / 1+r^{*}\right)\right]\right\}>1$, ceteris paribus. Thus, $R_{b}<R_{J}<R_{J, F}$. 
Table D1.a: Results from individual economies with the Joneses effect and the lagged dependent variable

\begin{tabular}{|c|c|c|c|c|c|c|c|c|c|c|}
\hline & China & India & Indonesia & Japan & Korea & Malaysia & Philippines & Singapore & Taiwan & Thailand \\
\hline l_rg_ratio & $\begin{array}{c}0.4985^{\star} \\
(2.08)\end{array}$ & $\begin{array}{c}0.7846^{\star \star *} \\
(5.07)\end{array}$ & $\begin{array}{c}0.4663^{\star \star \star} \\
(4.97)\end{array}$ & $\begin{array}{c}1.2046^{\star \star \star} \\
(11.45)\end{array}$ & $\begin{array}{c}0.6083^{\star \star \star} \\
(3.74)\end{array}$ & $\begin{array}{c}0.1440 \\
(0.60)\end{array}$ & $\begin{array}{l}0.3227 \\
(1.60)\end{array}$ & $\begin{array}{c}0.4969 * \\
(2.09)\end{array}$ & $\begin{array}{c}0.8043^{\star * *} \\
(3.31)\end{array}$ & $\begin{array}{c}0.7161^{\star \star \star} \\
(4.23)\end{array}$ \\
\hline lngdppc & $\begin{array}{c}0.0676 \\
(1.70)\end{array}$ & $\begin{array}{c}0.0839 * * \\
(2.45)\end{array}$ & $\begin{array}{c}-0.0053 \\
(-0.25)\end{array}$ & $\begin{array}{c}-0.0108 \\
(-0.79)\end{array}$ & $\begin{array}{c}0.0288 \\
(0.82)\end{array}$ & $\begin{array}{c}0.0869 \\
(0.60)\end{array}$ & $\begin{array}{c}-0.1090 \\
(-1.29)\end{array}$ & $\begin{array}{c}-0.0026 \\
(-0.02)\end{array}$ & $\begin{array}{c}-0.1000 \\
(-0.67)\end{array}$ & $\begin{array}{c}0.0045 \\
(0.11)\end{array}$ \\
\hline $\mathrm{mp}$ & $\begin{array}{l}-0.1689 \\
(-0.53)\end{array}$ & $\begin{array}{c}-0.5909 \\
(-1.36)\end{array}$ & $\begin{array}{l}0.1815 \\
(0.96)\end{array}$ & $\begin{array}{c}-0.1153 \\
(-0.93)\end{array}$ & $\begin{array}{l}0.0995 \\
(0.37)\end{array}$ & $\begin{array}{l}0.0480 \\
(0.25)\end{array}$ & $\begin{array}{c}0.3326^{\star \star} \\
(2.80)\end{array}$ & $\begin{array}{c}-0.2256^{\star \star} \\
(-2.44)\end{array}$ & $\begin{array}{c}-0.1201 \\
(-0.19)\end{array}$ & $\begin{array}{c}0.0308 \\
(0.28)\end{array}$ \\
\hline F_open & $\begin{array}{c}-0.3115 \\
(-0.83)\end{array}$ & $\begin{array}{l}-0.1535 \\
(-0.80)\end{array}$ & $\begin{array}{l}0.0397 \\
(0.10)\end{array}$ & $\begin{array}{l}-0.0327 \\
(-1.13)\end{array}$ & $\begin{array}{c}-0.1319 \\
(-0.67)\end{array}$ & $\begin{array}{c}-0.0216 \\
(-0.09)\end{array}$ & $\begin{array}{c}0.0979 * * \\
(2.16)\end{array}$ & $\begin{array}{c}-0.0746 \\
(-1.37)\end{array}$ & $\begin{array}{c}-0.0040 \\
(-0.01)\end{array}$ & $\begin{array}{c}0.4491^{\star \star \star} \\
(4.15)\end{array}$ \\
\hline E_vol & $\begin{array}{c}-0.0381 \\
(-0.56)\end{array}$ & $\begin{array}{c}-0.0021 \\
(-0.85)\end{array}$ & $\begin{array}{c}0.0001^{* * *} \\
(3.41)\end{array}$ & $\begin{array}{c}-0.0001 \\
(-0.43)\end{array}$ & $\begin{array}{c}-0.0002^{*} \\
(-2.03)\end{array}$ & $\begin{array}{c}-0.2103 \\
(-1.91)\end{array}$ & $\begin{array}{c}-0.0072 \\
(-1.73)\end{array}$ & $\begin{array}{c}0.0739 \\
(0.12)\end{array}$ & $\begin{array}{c}0.0123 \\
(0.51)\end{array}$ & $\begin{array}{c}-0.0041 \\
(-1.44)\end{array}$ \\
\hline R_vol & $\begin{array}{c}0.0029 * * \\
(2.50)\end{array}$ & $\begin{array}{c}0.0079^{\star * *} \\
(4.96)\end{array}$ & $\begin{array}{c}0.0028 \\
(0.24)\end{array}$ & $\begin{array}{c}0.0005^{\star \star \star} \\
(4.83)\end{array}$ & $\begin{array}{c}0.0112^{\star \star \star} \\
(5.58)\end{array}$ & $\begin{array}{c}0.0385^{\star \star *} \\
(3.00)\end{array}$ & $\begin{array}{c}0.0005 \\
(0.03)\end{array}$ & $\begin{array}{c}0.0316^{\star \star} \\
(2.21)\end{array}$ & $\begin{array}{c}0.0089^{\star} \\
(1.86)\end{array}$ & $\begin{array}{c}-0.0084 \\
(-1.68)\end{array}$ \\
\hline Joneses_4 & $\begin{array}{c}-0.0348 \\
(-0.74)\end{array}$ & $\begin{array}{c}-0.0364^{\star} \\
(-2.02)\end{array}$ & $\begin{array}{c}0.0270 \\
(1.55)\end{array}$ & $\begin{array}{c}-0.0114 \\
(-1.09)\end{array}$ & $\begin{array}{c}-0.0283 \\
(-1.11)\end{array}$ & $\begin{array}{c}0.0478 \\
(0.77)\end{array}$ & $\begin{array}{l}-0.002 \\
(-0.09)\end{array}$ & $\begin{array}{c}0.0999 \\
(1.67)\end{array}$ & $\begin{array}{l}0.2832 \\
(1.19)\end{array}$ & $\begin{array}{c}0.0662^{\star \star} \\
(2.88)\end{array}$ \\
\hline constant & $\begin{array}{l}-0.3192 \\
(-1.62)\end{array}$ & $\begin{array}{c}-0.4067^{\star *} \\
(-2.57)\end{array}$ & $\begin{array}{c}0.0162 \\
(0.14)\end{array}$ & $\begin{array}{c}0.1230 \\
(0.81)\end{array}$ & $\begin{array}{c}-0.2444 \\
(-0.69)\end{array}$ & $\begin{array}{c}-0.5642 \\
(-0.56)\end{array}$ & $\begin{array}{c}0.6913 \\
(1.22)\end{array}$ & $\begin{array}{c}0.6830 \\
(0.61)\end{array}$ & $\begin{array}{c}0.9518 \\
(0.71)\end{array}$ & $\begin{array}{c}-0.0631 \\
(-0.22)\end{array}$ \\
\hline Adj R-Squared & 0.9267 & 0.9665 & 0.9305 & 0.9907 & 0.9613 & 0.7795 & 0.9031 & 0.899 & 0.9295 & 0.9718 \\
\hline Observations & 23 & 23 & 24 & 24 & 24 & 23 & 24 & 24 & 15 & 24 \\
\hline
\end{tabular}

Note: The table reports the results of estimating model (22) economy by economy. "l_rg_ratio" is the lagged dependent variable, "Ingdppc” is the $\log$ per capita GDP, “mp" is the import propensity, "F_open” is financial openness, "E_Vol” is exchange volatility, and "R_vol” is international reserve volatility. "Joneses_4" is the Joneses variable defined by equation (24) in the text. t-statistics are in parentheses. “***”, “**”, and “*” denote significance at the $1 \%, 5 \%$ and $10 \%$ level, respectively. 
Table D1.b: Results from individual economies with period-specified Joneses effects and the lagged dependent variable

\begin{tabular}{|c|c|c|c|c|c|c|c|c|c|c|}
\hline & China & India & Indonesia & Japan & Korea & Malaysia & Philippines & Singapore & Taiwan & Thailand \\
\hline \multirow{2}{*}{ L_rg_ratio } & 0.1121 & $0.5796^{\star \star \star}$ & $0.3748^{\star \star \star}$ & $1.2629^{\star \star \star}$ & 0.1587 & 0.1549 & 0.1712 & $0.5643^{\star \star}$ & 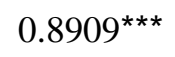 & 0.2653 \\
\hline & $(0.37)$ & (3.82) & (3.07) & (8.06) & $(0.89)$ & $(0.70)$ & $(1.12)$ & (2.66) & (3.49) & (1.37) \\
\hline \multirow{2}{*}{ lngdppc } & $0.0716^{\star}$ & $0.0632 *$ & 0.0016 & -0.0112 & 0.0364 & -0.0449 & $-0.1867^{\star *}$ & -0.0673 & -0.0432 & 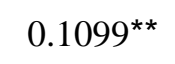 \\
\hline & (1.94) & (2.11) & $(0.07)$ & $(-0.80)$ & (1.35) & $(-0.30)$ & $(-2.88)$ & $(-0.62)$ & $(-0.27)$ & (2.32) \\
\hline \multirow{2}{*}{$\mathrm{mp}$} & -0.3236 & -0.5682 & 0.2016 & -0.1313 & 0.0118 & 0.1462 & 0.2740 & $-0.2260^{\star \star}$ & -0.1875 & 0.0017 \\
\hline & $(-1.05)$ & $(-1.55)$ & $(1.08)$ & $(-1.00)$ & $(0.06)$ & $(0.80)$ & (3.10) & $(-2.77)$ & $(-0.29)$ & $(0.02)$ \\
\hline \multirow{2}{*}{ F_open } & -0.0763 & 0.1309 & 0.0733 & -0.0306 & -0.0598 & -0.1030 & $0.0714^{\star \star}$ & -0.0804 & -0.0697 & $0.4030^{\star \star \star}$ \\
\hline & $(-0.21)$ & $(0.68)$ & $(0.19)$ & $(-1.03)$ & $(-0.39)$ & $(-0.47)$ & (2.11) & $(-1.67)$ & $(-0.21)$ & (4.63) \\
\hline \multirow{2}{*}{ E_vol } & -0.0197 & -0.0014 & $0.0000^{\star \star \star}$ & -0.0001 & -0.0001 & -0.1486 & $-0.0054^{\star}$ & 0.1568 & -0.0013 & $-0.0073^{\star \star \star}$ \\
\hline & $(-0.31)$ & $(-0.70)$ & (3.12) & $(-0.37)$ & $(-1.39)$ & $(-1.38)$ & $(-1.77)$ & $(0.29)$ & $(-0.05)$ & $(-2.98)$ \\
\hline \multirow{2}{*}{ R_vol } & $0.0034^{\star \star \star}$ & $0.0079 \star \star \star *$ & -0.0024 & $0.0005^{\star \star *}$ & 0.0010 & $0.0440^{\star \star \star}$ & 0.0225 & $0.0360^{\star \star}$ & 0.0089 & -0.0045 \\
\hline & (3.08) & (5.87) & $(-0.19)$ & (4.68) & $(0.30)$ & (3.58) & $(1.44)$ & $(2.81)$ & (1.88) & $(-1.09)$ \\
\hline \multirow{2}{*}{ Joneses_4 } & -0.0333 & $-0.0420^{\star \star}$ & 0.0092 & -0.0135 & -0.0095 & 0.0113 & $-0.0433^{\star *}$ & 0.0201 & -0.0625 & 0.0123 \\
\hline & $(-0.77)$ & $(-2.74)$ & $(0.39)$ & $(-1.18)$ & $(-0.47)$ & $(0.19)$ & $(-2.17)$ & $(0.32)$ & $(-0.15)$ & $(0.50)$ \\
\hline \multirow{2}{*}{$\begin{array}{c}\mathrm{I}>97 * \text { Joneses_ } \\
4\end{array}$} & $0.0718^{\star}$ & $0.0277^{\star *}$ & 0.0229 & -0.0044 & $0.1674^{\star \star \star}$ & $0.0724^{\star}$ & $0.0707^{\star \star \star}$ & $0.0780^{\star \star}$ & 0.2408 & $0.0590^{\star \star \star}$ \\
\hline & (1.85) & (2.66) & (1.15) & $(-0.51)$ & (3.50) & (1.84) & (3.87) & (2.34) & (1.04) & (3.23) \\
\hline \multirow{2}{*}{ constant } & -0.3137 & $-0.2896^{\star}$ & -0.0158 & 0.1279 & -0.2714 & 0.4213 & $1.2542^{\star \star}$ & 1.2787 & 0.4801 & $-0.7292^{\star \star}$ \\
\hline & $(-1.72)$ & $(-2.06)$ & $(-0.13)$ & $(0.83)$ & $(-1.00)$ & $(0.39)$ & (2.85) & $(1.26)$ & $(0.34)$ & $(-2.37)$ \\
\hline Adj R-Squared & 0.9369 & 0.9761 & 0.9319 & 0.9903 & 0.9773 & 0.8097 & 0.9482 & 0.9211 & 0.9303 & 0.9823 \\
\hline Observations & 23 & 23 & 24 & 24 & 24 & 23 & 24 & 24 & 15 & 24 \\
\hline
\end{tabular}

Note: The table reports the results of estimating model (22) economy by economy. "l_rg_ratio" is the lagged dependent variable, "Ingdppc" is the log per capita GDP, "mp” is the import propensity, "F_open" is financial openness, "E_Vol” is exchange volatility, and "R_vol” is international reserve volatility. "Joneses_4" is the Joneses variable defined by equation (24) in the text. "I>97*Joneses_4" is the interactive Joneses variable $\mathrm{I}(\mathrm{t}-1>97) * J_{i, t-1}$. t-statistics are in parentheses. “***”, “**”, and “*” denote significance at the $1 \%$, 5\% and $10 \%$ level, respectively. 
Table D2.a: Results from individual economies with the Joneses effect defined by the crisis_5 economies

\begin{tabular}{cccccccccccc}
\hline & China & India & Indonesia & Japan & Korea & Malaysia & Philippines & Singapore & Taiwan & Thailand \\
\hline \multirow{2}{*}{ Ingdppc } & $0.0959^{* *}$ & 0.0385 & -0.0474 & 0.0820 & 0.0709 & 0.0150 & -0.0644 & 0.0228 & $-0.4615^{* *}$ & $0.1383^{* * *}$ \\
& $(2.33)$ & $(0.18)$ & $(-1.51)$ & $(1.20)$ & $(1.72)$ & $(0.09)$ & $(-0.79)$ & $(0.15)$ & $(-2.43)$ & $(4.51)$ \\
mp & $-0.5857^{*}$ & $0.8278^{*}$ & 0.2250 & $0.8574^{* *}$ & $0.7092^{* * *}$ & 0.0955 & $0.3557^{* * *}$ & $-0.2470^{* *}$ & $1.7393^{* * *}$ & 0.1394 \\
& $(-2.05)$ & $(2.27)$ & $(0.98)$ & $(2.70)$ & $(2.97)$ & $(0.56)$ & $(3.03)$ & $(-2.10)$ & $(3.48)$ & $(1.22)$ \\
F_open & -0.0748 & -0.0397 & -0.3345 & 0.0829 & $-0.4380^{* *}$ & -0.1367 & $0.1119 * *$ & -0.0686 & 0.3134 & $0.3117^{* * *}$ \\
& $(-0.21)$ & $(-0.11)$ & $(-0.77)$ & $(0.64)$ & $(-2.36)$ & $(-0.67)$ & $(2.51)$ & $(-1.07)$ & $(0.62)$ & $(3.00)$ \\
E_vol & -0.0106 & -0.0047 & $0.0001^{* * *}$ & -0.0004 & $-0.0003^{* * *}$ & $-0.1889^{*}$ & -0.0067 & -0.3011 & -0.0124 & -0.0031 \\
& $(-0.14)$ & $(-1.22)$ & $(4.07)$ & $(-0.38)$ & $(-3.31)$ & $(-1.86)$ & $(-1.63)$ & $(-0.43)$ & $(-0.38)$ & $(-0.96)$ \\
R_vol & $0.0047^{* * *}$ & $0.0104^{* * *}$ & -0.0080 & $0.0013^{* *}$ & $0.0115^{* * *}$ & $0.0442 * * *$ & -0.0029 & $0.0430^{* *}$ & $0.0162^{* *}$ & $-0.0115^{*}$ \\
& $(5.39)$ & $(5.75)$ & $(-0.57)$ & $(2.71)$ & $(5.08)$ & $(3.70)$ & $(-0.15)$ & $(2.45)$ & $(2.64)$ & $(-2.10)$ \\
Joneses_5 & -0.0360 & -0.0145 & $0.1175^{* * *}$ & 0.0340 & 0.0812 & 0.1127 & 0.0410 & $0.1942 * *$ & 0.0225 & $0.1152^{* * *}$ \\
& $(-0.73)$ & $(-0.51)$ & $(3.70)$ & $(1.02)$ & $(1.72)$ & $(1.23)$ & $(1.00)$ & $(2.23)$ & $(0.16)$ & $(3.44)$ \\
constant & $-0.4511^{* *}$ & -0.0925 & 0.2882 & -0.9120 & $-0.7807 * *$ & 0.0002 & 0.3795 & 0.7658 & $3.9534^{* *}$ & $-0.9697 * * *$ \\
& $(-2.41)$ & $(-0.51)$ & $(1.59)$ & $(-1.28)$ & $(-2.01)$ & $(0.00)$ & $(0.70)$ & $(0.50)$ & $(2.38)$ & $(-4.66)$ \\
Adj R-squares & 0.9127 & 0.9382 & 0.8971 & 0.8025 & 0.9373 & 0.7971 & 0.9000 & 0.8540 & 0.8242 & 0.9637 \\
Observations & 23 & 23 & 24 & 24 & 24 & 23 & 24 & 24 & 15 & 24 \\
\hline
\end{tabular}

Note: The table reports the results of estimating model (21) economy by economy. "Ingdppc” is log per capita GDP, “mp” is propensity to imports, "F_open” is financial openness, "E-Vol” is exchange volatility, and "R_vol” is reserve volatility. "Joneses_5" is the Joneses variable defined as the sum of the reserve-to-GDP ratio of five 1997-98 crisis affected economies, which are Indonesia, Korea, Malaysia, Philippines and Thailand. t-statistics are in parentheses. “***”, “**”, and “*” denote significance at the $1 \%, 5 \%$ and $10 \%$ level, respectively. 
Table D2.b: Results for individual economies with period-specified Joneses effects, with the crisis_5 economies as the Joneses

\begin{tabular}{cccccccccccc}
\hline & China & India & Indonesia & Japan & Korea & Malaysia & Philippines & Singapore & Taiwan & Thailand \\
\hline \multirow{2}{*}{ lngdppc } & $0.0860^{* *}$ & -0.0385 & 0.0391 & 0.0978 & $0.0647^{* *}$ & 0.0222 & -0.0954 & 0.0837 & $-0.6587^{* *}$ & $0.1733^{* * *}$ \\
& $(2.46)$ & $(-1.02)$ & $(1.05)$ & $(1.50)$ & $(2.12)$ & $(0.15)$ & $(-1.43)$ & $(0.54)$ & $(-2.64)$ & $(7.15)$ \\
mp & -0.3675 & $0.6704^{* *}$ & 0.2864 & $0.7182^{* *}$ & $0.3763^{*}$ & 0.2029 & $0.2816^{* *}$ & -0.1905 & $1.9971^{* * *}$ & 0.0526 \\
& $(-1.44)$ & $(2.37)$ & $(1.53)$ & $(2.32)$ & $(1.92)$ & $(1.22)$ & $(2.86)$ & $(-1.59)$ & $(3.74)$ & $(0.65)$ \\
F_open & 0.0695 & 0.5222 & -0.0866 & 0.0184 & -0.1528 & -0.1550 & 0.0562 & -0.0504 & 0.3601 & $0.2882^{* * *}$ \\
& $(0.23)$ & $(1.62)$ & $(-0.24)$ & $(0.14)$ & $(-0.98)$ & $(-0.82)$ & $(1.39)$ & $(-0.80)$ & $(0.72)$ & $(4.10)$ \\
E_vol & -0.0271 & -0.0014 & $0.0000^{*}$ & -0.0009 & $-0.0003^{* * *}$ & $-0.2115^{* *}$ & -0.0054 & -0.5142 & 0.0601 & $-0.0080^{* * *}$ \\
& $(-0.42)$ & $(-0.44)$ & $(2.11)$ & $(-0.78)$ & $(-3.46)$ & $(-2.14)$ & $(-1.60)$ & $(-0.74)$ & $(0.87)$ & $(-3.27)$ \\
R_vol & $0.0042 * * *$ & $0.0097 * * *$ & -0.0097 & $0.0013 * *$ & $0.0080^{* * *}$ & $0.0529 * * *$ & 0.0265 & $0.0507 * *$ & $0.0162 * *$ & -0.0001 \\
& $(5.57)$ & $(6.93)$ & $(-0.86)$ & $(2.68)$ & $(4.20)$ & $(4.46)$ & $(1.49)$ & $(2.85)$ & $(2.70)$ & $(-0.03)$ \\
Joneses_5 & -0.0549 & 0.0043 & -0.0382 & -0.0177 & -0.0053 & -0.1818 & -0.0015 & 0.0147 & 0.3843 & -0.0396 \\
& $(-1.02)$ & $(0.20)$ & $(-0.69)$ & $(-0.41)$ & $(-0.13)$ & $(-1.05)$ & $(-0.04)$ & $(0.10)$ & $(1.15)$ & $(-0.95)$ \\
I>97*Joneses_5 & $0.0543^{* *}$ & $0.0322^{* * *}$ & $0.0814 * * *$ & $0.0345^{*}$ & $0.0853^{* * *}$ & $0.1590^{*}$ & $0.0591 * * *$ & 0.0837 & -0.1784 & $0.0965 * * *$ \\
& $(2.71)$ & $(3.49)$ & $(3.18)$ & $(1.77)$ & $(3.89)$ & $(1.95)$ & $(3.11)$ & $(1.46)$ & $(-1.18)$ & $(4.45)$ \\
constant & $-0.3835^{*}$ & 0.1752 & -0.2146 & -1.0322 & $-0.6123^{*}$ & -0.0492 & 0.6172 & 0.1704 & $5.4239 * *$ & $-1.1423^{* * *}$ \\
& $(-2.13)$ & $(0.89)$ & $(-1.00)$ & $(-1.52)$ & $(-2.11)$ & $(-0.04)$ & $(1.37)$ & $(0.11)$ & $(2.66)$ & $(-7.69)$ \\
Adj. R-squares & 0.9375 & 0.9500 & 0.9330 & 0.8247 & 0.9658 & 0.8273 & 0.9337 & 0.8631 & 0.8326 & 0.9828 \\
Observations & 23 & 23 & 24 & 24 & 24 & 23 & 24 & 24 & 15 & 24 \\
\hline
\end{tabular}

Note: The table reports the results of estimating model (22) economy by economy. "Ingdppc" is the log per capita GDP, "mp” is the import propensity, "F_open” is financial openness, "E_Vol” is exchange volatility, and "R_vol” is reserve volatility. "Joneses” is the Joneses variable defined as the sum of the reserve-to-GDP ratio of five 1997-98 crisis affected economies, which are Indonesia, Korea, Malaysia, Philippines and Thailand. "I $>97 *$ Joneses_5” is the interactive Joneses variable I(t-1>97)* $J_{i, t-1}$. t-statistics are in parentheses. “***”, “**”, and “*” denote significance at the $1 \%, 5 \%$ and $10 \%$ level, respectively. 
Table D3.a: Results from individual economies with the Joneses variable and the common GDP growth element

\begin{tabular}{|c|c|c|c|c|c|c|c|c|c|c|}
\hline & China & India & Indonesia & Japan & Korea & Malaysia & Philippine & Singapore & Taiwan & Thailand \\
\hline \multirow{2}{*}{ lngdppc } & 0.0815 & -0.0530 & -0.0342 & $-0.0924^{\star *}$ & 0.0548 & -0.1218 & -0.0097 & -0.0262 & $-0.5533^{\star *}$ & $0.0807^{\star \star \star}$ \\
\hline & (1.70) & $(-0.72)$ & $(-0.86)$ & $(-2.36)$ & (1.34) & $(-0.82)$ & $(-0.11)$ & $(-0.23)$ & $(-2.46)$ & $(2.46)$ \\
\hline \multirow{2}{*}{$\mathrm{mp}$} & -0.3938 & $0.9496^{\star \star}$ & 0.4083 & $0.6336^{\star \star \star}$ & $0.8048^{\star \star \star}$ & 0.1984 & 0.2211 & $-0.2576^{\star \star}$ & $1.5118^{\star \star}$ & $0.1676^{*}$ \\
\hline & $(-1.19)$ & (2.29) & $(1.57)$ & $(4.41)$ & $(4.47)$ & (1.28) & (1.44) & $(-2.55)$ & (2.38) & $(1.76)$ \\
\hline \multirow{2}{*}{ F_open } & -0.3108 & -0.1140 & -0.6185 & 0.0029 & $-0.5060^{\star \star \star}$ & 0.0294 & $0.1528^{\star \star \star}$ & -0.0572 & 0.1614 & $0.4548^{\star \star \star}$ \\
\hline & $(-0.81)$ & $(-0.37)$ & $(-1.28)$ & $(0.04)$ & $(-3.08)$ & $(0.16)$ & (3.96) & $(-1.08)$ & $(0.30)$ & (4.22) \\
\hline \multirow{2}{*}{ E_vol } & -0.0249 & -0.0052 & $0.0001^{\star \star}$ & -0.0001 & $-0.0005^{\star \star *}$ & $-0.2501^{\star \star}$ & -0.0066 & -0.3496 & -0.0113 & $-0.0114^{\star \star}$ \\
\hline & $(-0.32)$ & $(-1.53)$ & (2.38) & $(-0.13)$ & $(-5.42)$ & $(-2.57)$ & $(-1.61)$ & $(-0.53)$ & $(-0.23)$ & $(-2.85)$ \\
\hline \multirow{2}{*}{ R_vol } & $0.0040^{\star * \star}$ & $0.0104^{\star * \star}$ & -0.0057 & $0.0005^{\star}$ & $0.0049 *$ & $0.0434^{\star \star *}$ & 0.0043 & $0.0363^{\star \star}$ & $0.0146^{\star}$ & $-0.0039 *$ \\
\hline & & & & (1.96) & (1.80) & (4.14) & $(0.23)$ & (2.53) & $(2.20)$ & $(-0.67)$ \\
\hline \multirow{2}{*}{ Joneses } & 0.0342 & 0.0306 & $0.0383^{\star}$ & $0.0738^{\star \star *}$ & $0.0824^{\star *}$ & $0.0910^{\star *}$ & 0.0311 & $0.1621^{\star \star \star}$ & 0.0834 & $0.0688^{\star \star \star}$ \\
\hline & $(0.77)$ & $(1.34)$ & $(2.10)$ & & (2.57) & $(2.40)$ & (1.61) & (3.97) & $(0.66)$ & (4.26) \\
\hline \multirow{2}{*}{ PC_gdp-growth } & -0.1168 & $-0.0681^{\star \star}$ & 0.0259 & -0.0728 & $-0.2065^{\star \star *}$ & $-0.1760^{\star \star}$ & -0.0847 & -0.0774 & -0.0099 & $-0.1195^{\star \star}$ \\
\hline & $(-1.59)$ & $(-2.14)$ & $(0.32)$ & $(-3.42)$ & $(-3.67)$ & $(-2.16)$ & $(-1.71)$ & $(-0.73)$ & $(-0.05)$ & $(-2.70)$ \\
\hline \multirow{2}{*}{ constant } & $-0.4159 *$ & 0.2067 & 0.1736 & $0.8080^{\star}$ & $-0.7453^{\star \star}$ & 0.8957 & 0.0063 & 1.1903 & $4.7858^{\star \star}$ & $-0.6420^{\star \star \star}$ \\
\hline & $(-1.89)$ & $(0.58)$ & $(0.80)$ & $(2.01)$ & $(-2.17)$ & $(0.86)$ & $(0.01)$ & $(1.04)$ & & $(-3.13)$ \\
\hline Adj R-squares & 0.9191 & 0.9299 & 0.8604 & 0.9504 & 0.9576 & 0.8450 & 0.9063 & 0.8993 & 0.8118 & 0.9717 \\
\hline Observations & 23 & 23 & 24 & 24 & 24 & 23 & 24 & 24 & 15 & 24 \\
\hline
\end{tabular}

Note: The table reports the results of estimating model (21) economy by economy. "Ingdppc” is log per capita GDP, “mp” is propensity to imports, "F_open" is financial openness, "E-Vol” is exchange volatility, and "R_vol” is reserve volatility. "Joneses" is the Joneses variable defined by equation (23) in the text. "PC_gdp_growth" is the principal component of the sample economies' growth rates. t-statistics are in parentheses. “***”, “**”, and “*” denote significance at the $1 \%, 5 \%$ and $10 \%$ level, respectively. 
Table D3.b: Results for individual economies with period-specified Joneses effects and the common growth element

\begin{tabular}{|c|c|c|c|c|c|c|c|c|c|c|}
\hline & China & India & Indonesia & Japan & Korea & Malaysia & Philippines & Singapore & Taiwan & Thailand \\
\hline \multirow{2}{*}{ lngdppc } & $0.0932^{\star \star}$ & -0.0374 & 0.0654 & $-0.1213^{\star \star \star}$ & 0.0266 & -0.1210 & -0.1751 & -0.0249 & $-1.1154^{\star \star \star}$ & $0.1555^{\star \star \star}$ \\
\hline & $(2.21)$ & $(-0.57)$ & $(1.84)$ & $(-3.07)$ & $(0.84)$ & $(-0.78)$ & $(-1.84)$ & $(-0.20)$ & $(-4.37)$ & $(4.97)$ \\
\hline \multirow{2}{*}{$\mathrm{mp}$} & -0.2495 & $0.6922^{*}$ & 0.1994 & $0.7556^{\star \star \star}$ & $0.3476^{*}$ & 0.1998 & $0.4090^{\star *}$ & $-0.2576^{\star \star}$ & $1.0426^{\star}$ & 0.0518 \\
\hline & $(-0.84)$ & $(1.81)$ & $(1.08)$ & $(4.81)$ & $(1.90)$ & $(1.24)$ & $(2.81)$ & $(-2.47)$ & $(2.17)$ & $(0.68)$ \\
\hline \multirow{2}{*}{ F_open } & -0.0646 & 0.3443 & -0.0585 & 0.0283 & -0.2057 & 0.0177 & 0.0500 & -0.0571 & 0.0963 & $0.3134^{\star \star \star}$ \\
\hline & $(-0.18)$ & $(1.02)$ & $(-0.16)$ & $(0.45)$ & $(-1.40)$ & $(0.08)$ & $(1.02)$ & $(-1.04)$ & $(0.25)$ & (3.56) \\
\hline \multirow{2}{*}{ E_vol } & -0.0379 & -0.0026 & $0.0001^{\star * *}$ & -0.0000 & $-0.0003^{\star \star *}$ & $-0.2435^{\star}$ & -0.0063 & -0.3428 & $0.1043^{*}$ & $-0.0102^{\star \star \star}$ \\
\hline & $(-0.56)$ & $(-0.81)$ & (3.05) & $(-0.01)$ & $(-3.23)$ & $(-2.01)$ & $(-1.83)$ & $(-0.48)$ & $(1.94)$ & $(-3.42)$ \\
\hline \multirow{2}{*}{ R_vol } & $0.0040^{\star \star \star}$ & $0.0098^{\star \star \star}$ & -0.0137 & $0.0006^{\star \star}$ & 0.0031 & $0.0438^{\star \star \star}$ & 0.0244 & $0.0364^{\star \star}$ & $0.0117^{*}$ & 0.0005 \\
\hline & (4.93) & (5.89) & $(-1.21)$ & $(2.41)$ & $(1.46)$ & $(3.71)$ & (1.39) & $(2.35)$ & $(2.43)$ & $(0.11)$ \\
\hline \multirow{2}{*}{ Joneses } & -0.0401 & 0.0070 & -0.0353 & $0.0947^{\star \star *}$ & $0.0471^{*}$ & 0.0858 & -0.0301 & $0.1596^{*}$ & $0.6577^{\star *}$ & 0.0045 \\
\hline & $(-0.80)$ & $(0.31)$ & $(-1.67)$ & $(6.56)$ & (1.83) & $(1.30)$ & $(-1.10)$ & $(1.78)$ & $(2.96)$ & $(0.22)$ \\
\hline \multirow{2}{*}{$\begin{array}{l}\text { PC_gdp_growt } \\
\mathrm{h}\end{array}$} & 0.0126 & -0.0175 & $0.1069 *$ & $-0.1059 * \star *$ & $-0.0951^{\star}$ & -0.1650 & 0.0524 & -0.0738 & -0.2426 & -0.0353 \\
\hline & $(0.15)$ & $(-0.49)$ & $(1.80)$ & $(-4.00)$ & $(-1.83)$ & $(-1.17)$ & $(0.81)$ & $(-0.46)$ & $(-1.50)$ & $(-0.89)$ \\
\hline \multirow{2}{*}{$\mathrm{I}>97 *$ Joneses } & $0.0221^{\star \star}$ & $0.0115^{\star \star}$ & $0.0320^{\star \star \star}$ & $-0.0092^{\star}$ & $0.0300^{\star \star \star}$ & 0.0023 & $0.0286^{\star \star}$ & 0.0011 & $-0.1706^{\star \star}$ & $0.0256^{\star \star \star}$ \\
\hline & $(2.36)$ & $(2.30)$ & $(4.35)$ & $(-1.89)$ & (3.69) & $(0.10)$ & $(2.78)$ & $(0.03)$ & $(-2.82)$ & (3.79) \\
\hline \multirow{2}{*}{ constant } & $-0.3974^{\star}$ & 0.1632 & -0.3305 & $1.0611^{\star \star}$ & -0.3411 & 0.8957 & $1.1733^{*}$ & 1.1805 & $9.2433^{\star * *}$ & $-1.0365^{\star \star \star}$ \\
\hline & $(-2.06)$ & $(0.51)$ & $(-1.76)$ & $(2.67)$ & $(-1.22)$ & $(0.83)$ & $(1.80)$ & $(0.97)$ & $(4.35)$ & $(-5.64)$ \\
\hline \multirow{2}{*}{$\begin{array}{l}\text { Adj. R-squares } \\
\text { Observations }\end{array}$} & 0.9372 & 0.9455 & 0.9341 & 0.9572 & 0.9763 & 0.8340 & 0.9341 & 0.8926 & 0.9055 & 0.9846 \\
\hline & 23 & 23 & 24 & 24 & 24 & 23 & 24 & 24 & 15 & 24 \\
\hline
\end{tabular}

Note: The table reports the results of estimating model (22) economy by economy. "Ingdppc” is the log per capita GDP, "mp” is the import propensity, "F_open” is financial openness, "E_Vol” is exchange volatility, and "R_vol” is reserve volatility. "Joneses" is the Joneses variable defined by equation (23) in the text. "PC_gdp_growth" is the principal component of the sample economies' growth rates. "I>97*Joneses" is the interactive Joneses variable $\mathrm{I}(\mathrm{t}-1>97) * J_{i, t-1}$. t-statistics are in parentheses. “***”, “**”, and “*” denote significance at the $1 \%, 5 \%$ and $10 \%$ level, respectivel 


\section{CESifo Working Paper Series}

(for full list see www.cesifo-group.de)

2004 Harrie A. A. Verbon, Migrating Football Players, Transfer Fees and Migration Controls, May 2007

2005 Helmuth Cremer, Jean-Marie Lozachmeur and Pierre Pestieau, Income Taxation of Couples and the Tax Unit Choice, May 2007

2006 Michele Moretto and Paolo M. Panteghini, Preemption, Start-Up Decisions and the Firms’ Capital Structure, May 2007

2007 Andreas Schäfer and Thomas M. Steger, Macroeconomic Consequences of Distributional Conflicts, May 2007

2008 Mikael Priks, Judiciaries in Corrupt Societies, June 2007

2009 Steinar Holden and Fredrik Wulfsberg, Downward Nominal Wage Rigidity in the OECD, June 2007

2010 Emmanuel Dhyne, Catherine Fuss, Hashem Pesaran and Patrick Sevestre, Lumpy Price Adjustments: A Microeconometric Analysis, June 2007

2011 Paul Belleflamme and Eric Toulemonde, Negative Intra-Group Externalities in TwoSided Markets, June 2007

2012 Carlos Alós-Ferrer, Georg Kirchsteiger and Markus Walzl, On the Evolution of Market Institutions: The Platform Design Paradox, June 2007

2013 Axel Dreher and Martin Gassebner, Greasing the Wheels of Entrepreneurship? The Impact of Regulations and Corruption on Firm Entry, June 2007

2014 Dominique Demougin and Claude Fluet, Rules of Proof, Courts, and Incentives, June 2007

2015 Stefan Lachenmaier and Horst Rottmann, Effects of Innovation on Employment: A Dynamic Panel Analysis, June 2007

2016 Torsten Persson and Guido Tabellini, The Growth Effect of Democracy: Is it Heterogenous and how can it be Estimated?, June 2007

2017 Lorenz Blume, Jens Müller, Stefan Voigt and Carsten Wolf, The Economic Effects of Constitutions: Replicating - and Extending - Persson and Tabellini, June 2007

2018 Hartmut Egger and Gabriel Felbermayr, Endogenous Skill Formation and the Source Country Effects of International Labor Market Integration, June 2007

2019 Bruno Frey, Overprotected Politicians, June 2007 
2020 Jan Thomas Martini, Rainer Niemann and Dirk Simons, Transfer Pricing or Formula Apportionment? Tax-Induced Distortions of Multinationals' Investment and Production Decisions, June 2007

2021 Andreas Bühn, Alexander Karmann and Friedrich Schneider, Size and Development of the Shadow Economy and of Do-it-yourself Activities in Germany, June 2007

2022 Michael Rauscher and Edward B. Barbier, Biodiversity and Geography, June 2007

2023 Gunther Schnabl, Exchange Rate Volatility and Growth in Emerging Europe and East Asia, June 2007

2024 Erkki Koskela and Ronnie Schöb, Tax Progression under Collective Wage Bargaining and Individual Effort Determination, June 2007

2025 Jay Pil Choi and Marcel Thum, The Economics of Politically Connected Firms, June 2007

2026 Jukka Pirttilä and Roope Uusitalo, Leaky Bucket in the Real World: Estimating Inequality Aversion Using Survey Data, June 2007

2027 Ruslan Lukach, Peter M. Kort and Joseph Plasmans, Strategic R\&D with Knowledge Spillovers and Endogenous Time to Complete, June 2007

2028 Jarko Fidrmuc, Neil Foster and Johann Scharler, Labour Market Rigidities, Financial Integration and International Risk Sharing in the OECD, June 2007

2029 Bernardina Algieri and Thierry Bracke, Patterns of Current Account Adjustment Insights from Past Experience, June 2007

2030 Robert Dur and Hein Roelfsema, Social Exchange and Common Agency in Organizations, June 2007

2031 Alexander Libman and Lars P. Feld, Strategic Tax Collection and Fiscal Decentralisation: The Case of Russia, June 2007

2032 Øystein Foros, Hans Jarle Kind and Greg Shaffer, Resale Price Maintenance and Restrictions on Dominant Firm and Industry-Wide Adoption, June 2007

2033 Jan K. Brueckner and Kurt Van Dender, Atomistic Congestion Tolls at Concentrated Airports? Seeking a Unified View in the Internalization Debate, June 2007

2034 Viet Do and Ngo Van Long, International Outsourcing under Monopolistic Competition: Winners and Losers, June 2007

2035 Nadia Fiorino and Roberto Ricciuti, Determinants of Direct Democracy, June 2007

2036 Burkhard Heer and Alfred Maussner, Inflation and Output Dynamics in a Model with Labor Market Search and Capital Accumulation, June 2007 
2037 Konstantinos Angelopoulos, Jim Malley and Apostolis Philippopoulos, Public Education Expenditure, Growth and Welfare, June 2007

2038 Maarten Bosker, Steven Brakman, Harry Garretsen and Marc Schramm, Adding Geography to the New Economic Geography, June 2007

2039 Steffen Henzel, Oliver Hülsewig, Eric Mayer and Timo Wollmershäuser, The Price Puzzle Revisited: Can the Cost Channel Explain a Rise in Inflation after a Monetary Policy Shock?, July 2007

2040 Rosario Crinò, Service Offshoring and White-Collar Employment, July 2007

2041 Carsten Hefeker and Michael Neugart, Labor Market Regulation and the Legal System, July 2007

2042 Bart Cockx and Muriel Dejemeppe, Is the Notification of Monitoring a Threat to the Unemployed? A Regression Discontinuity Approach, July 2007

2043 Alfons J. Weichenrieder, Profit Shifting in the EU: Evidence from Germany, July 2007

2044 Annika Alexius and Bertil Holmlund, Monetary Policy and Swedish Unemployment Fluctuations, July 2007

2045 Axel Dreher, Jan-Egbert Sturm and Jakob de Haan, Does High Inflation Cause Central Bankers to Lose their Job? Evidence Based on a New Data Set, July 2007

2046 Guglielmo Maria Caporale and Luis A. Gil-Alana, Long Run and Cyclical Dynamics in the US Stock Market, July 2007

2047 Alessandro Balestrino, It is a Theft but not a Crime, July 2007

2048 Daniel Becker and Michael Rauscher, Fiscal Competition in Space and Time: An Endogenous-Growth Approach, July 2007

2049 Yannis M. Ioannides, Henry G. Overman, Esteban Rossi-Hansberg and Kurt Schmidheiny, The Effect of Information and Communication Technologies on Urban Structure, July 2007

2050 Hans-Werner Sinn, Please bring me the New York Times - On the European Roots of Richard Abel Musgrave, July 2007

2051 Gunther Schnabl and Christian Danne, A Role Model for China? Exchange Rate Flexibility and Monetary Policy in Japan, July 2007

2052 Joseph Plasmans, Jorge Fornero and Tomasz Michalak, A Microfounded Sectoral Model for Open Economies, July 2007

2053 Vesa Kanniainen and Panu Poutvaara, Imperfect Transmission of Tacit Knowledge and other Barriers to Entrepreneurship, July 2007 
2054 Marko Koethenbuerger, Federal Tax-Transfer Policy and Intergovernmental PreCommitment, July 2007

2055 Hendrik Jürges and Kerstin Schneider, What Can Go Wrong Will Go Wrong: Birthday Effects and Early Tracking in the German School System, July 2007

2056 Bahram Pesaran and M. Hashem Pesaran, Modelling Volatilities and Conditional Correlations in Futures Markets with a Multivariate t Distribution, July 2007

2057 Walter H. Fisher and Christian Keuschnigg, Pension Reform and Labor Market Incentives, July 2007

2058 Martin Altemeyer-Bartscher, Dirk T. G. Rübbelke and Eytan Sheshinski, Policies to Internalize Reciprocal International Spillovers, July 2007

2059 Kurt R. Brekke, Astrid L. Grasdal and Tor Helge Holmås, Regulation and Pricing of Pharmaceuticals: Reference Pricing or Price Cap Regulation?, July 2007

2060 Tigran Poghosyan and Jakob de Haan, Interest Rate Linkages in EMU Countries: A Rolling Threshold Vector Error-Correction Approach, July 2007

2061 Robert Dur and Klaas Staal, Local Public Good Provision, Municipal Consolidation, and National Transfers, July 2007

2062 Helge Berger and Anika Holler, What Determines Fiscal Policy? Evidence from German States, July 2007

2063 Ernesto Reuben and Arno Riedl, Public Goods Provision and Sanctioning in Privileged Groups, July 2007

2064 Jan Hanousek, Dana Hajkova and Randall K. Filer, A Rise by Any Other Name? Sensitivity of Growth Regressions to Data Source, July 2007

2065 Yin-Wong Cheung and Xing Wang Qian, Hoarding of International Reserves: Mrs Machlup's Wardrobe and the Joneses, July 2007 